\title{
MAPPING THE INTERNAL STRUCTURES OF FAULT ZONES OF THE SEDIMENTARY COVER: A TECTONOPHYSICAL APPROACH APPLIED TO INTERPRET TDEM DATA (KOVYKTA GAS CONDENSATE FIELD)
}

\author{
K. Zh. Seminsky, 2, I. V. Buddo1, 3, A. A. Bobrov', N. V. Misyurkeeva1, ${ }^{1}$, \\ Yu. P. Burzunova1, A. S. Smirnov ${ }^{4,5}$, I. A. Shelokhov ${ }^{1,3}$ \\ ${ }^{1}$ Institute of the Earth's Crust, Siberian Branch of RAS, Irkutsk, Russia \\ ${ }^{2}$ Irkutsk Scientific Center, Siberian Branch of RAS, Irkutsk, Russia \\ ${ }^{3}$ SIGMA-GEO LLC, Irkutsk, Russia \\ ${ }^{4}$ Gazprom Geological Exploration LLC, Tyumen, Russia \\ 5 Tyumen Industrial University, Tyumen, Russia
}

\begin{abstract}
The article presents the results of studying the internal structures of platform fault zones with the use of a new tectonophysical approach to processing and interpretation of electrical exploration data obtained by the transient electromagnetic method in the near field zone (TEM). In the study of the central part of the Kovykta gas condensate field (East Siberia, Russia), we applied the ideas of tectonophysics envisaging three stages of fault formation, which determine the three-membered transverse zoning of a fully formed fault zone. Each subzone is characterized by a certain level of rock disturbance and corresponding electrical conductivity. Based on the analysis of electrical conductivity values, the boundaries can be determined between locations differing by the degrees of rock disturbance of the sedimentary stratum. Using a map of this parameter, it becomes possible to generally establish the boundaries of fault zones and specify internal subzones. The new approach was applied to assess the electrical conductivity of the reservoirs of the Kovykta field. It is established that there are several zones of faulting in the sedimentary stratum, which have not reached a final stage of development when a single fault plane is formed. Currently, these are zones of increased fracturing and dense occurrence of second-order ruptures that are typical of platform settings due to their relatively weak tectonic activity. The zones are structurally non-uniform, as evidenced by rheological layering of the sedimentary cover in the vertical cross-section. A 3D electrical conductivity model of the largest fault zone in the study area shows alternating segments with more or less developed internal structures. Such segments are confined to layers that differ with respect to fracturing. Exploration and development of hydrocarbon deposits can benefit from 3D modeling of large fault zones with the use of the tectonophysical approach for processing and interpretation of the TEM data. The models can provide additional arguments for improved decision making about locations for trouble-free well drilling, as well as for selecting more effective methods for drilling sedimentary strata composed of complex horizontal layers.
\end{abstract}

Key words: fault zone; sedimentary cover; transient electromagnetic method (TEM); tectonophysics; Kovykta gas condensate field

RESEARCH ARTICLE

Received: August 10, 2019

Revised: September 7, 2019

Accepted: October 21, 2019

For citation: Seminsky K.Zh., Buddo I.V., Bobrov A.A., Misyurkeeva N.V., Burzunova Yu.P., Smirnov A.S., Shelokhov I.A., 2019. Mapping the internal structures of fault zones of the sedimentary cover: a tectonophysical approach applied to interpret TDEM data (Kovykta gas condensate field). Geodynamics \& Tectonophysics 10 (4), 879-897. doi:10.5800/GT-2019-10-4-0447. 


\title{
КАРТИРОВАНИЕ ВНУТРЕННЕЙ СТРУКТУРЫ РАЗЛОМНЫХ ЗОН ОСАДОЧНОГО ЧЕХЛА: ПРИМЕНЕНИЕ ТЕКТОНОФИЗИЧЕСКОГО ПОДХОДА К ИНТЕРПРЕТАЦИИ ДАННЫХ ЭЛЕКТРОРАЗВЕДКИ МЕТОДОМ ЗD ЗСБ (НА ПРИМЕРЕ КОВЫКТИНСКОГО ГАЗОКОНДЕНСАТНОГО МЕСТОРОЖДЕНИЯ)
}

\author{
К. Ж. Семинский ${ }^{1,2}$, И. В. Буддо ${ }^{1,3}$, А. А. Бобров ${ }^{1}$, Н. В. Мисюркеева ${ }^{1,3}$, \\ Ю. П. Бурзунова 1 , А. С. Смирнов ${ }^{4,5}$, И. А. Шелохов ${ }^{1,3}$
}

${ }^{1}$ Институт земной коры СО РАН, Иркутск, Россия

${ }^{2}$ Иркутский научный центр СО РАН, Иркутск, Россия

${ }^{3}$ ООО СИГМА-ГЕО, Иркутск, Россия

${ }^{4}$ ООо Газпром Геологоразведка, Тюмень, Россия

5 Тюменский индустриальный университет, Тюмень, Россия

\begin{abstract}
Аннотация: Статья посвящена результатам изучения внутреннего строения платформенных разломных зон на основе применения тектонофизического подхода к обработке и интерпретации материалов электроразведки методом зондирований становлением поля в ближней зоне (ЗСБ). Объектом исследования являлась разломная структура осадочной толщи на участке детальных работ ЗСБ, располагающемся в центральной части Ковыктинского газоконденсатного месторождения (Восточная Сибирь). Новый подход основан на представлениях тектонофизики о трех стадиях разломообразования, предопределяющих наличие у полностью сформированной разломной зоны трехчленной поперечной зональности. Каждой из подзон соответствуют определенные уровни нарушенности пород и, соответственно, их электропроводности. Анализ значений электрической проводимости, полученных для участка исследований, дает возможность определить границы уровней нарушенности осадочной толщи и затем выделить на картах распределения данного параметра границы разломных зон в целом и их внутренних подзон в частности. Применение нового подхода к оценке электропроводности в отдельных горизонтах-коллекторах Ковыктинской площади позволило установить, что осадочная толща нарушена системой разломных зон, большинство из которых не достигли заключительной стадии развития, когда формируется поверхность единого сместителя. Они представляют зоны повышенной трещиноватости и сгущения разрывов 2-го порядка, характерные для платформ ввиду их относительно слабой тектонической активности. Установлена продольная неравномерность в строении зон, которая в вертикальном разрезе определяется реологической расслоенностью осадочного чехла. В объемной модели электропроводности, построенной для наиболее крупной разломной зоны участка исследований, имеет место чередование сегментов с более и менее развитой внутренней структурой, приуроченных к слоям с разной компетентностью по отношению к процессу разрывообразования. Трехмерные модели крупных разломных зон, созданные посредством тектонофизического подхода к обработке и интерпретации данных электроразведки методом ЗСБ, представляют практический интерес для разведки и эксплуатации месторождений углеводородного сырья. Они являются дополнительной основой для принятия решений о местах проходки безаварийных скважин, а также эффективных способах разбуривания сложнодислоцированной горизонтально-слоистой осадочной толщи.
\end{abstract}

Ключевые слова: разломная зона; осадочный чехол; электроразведка методом ЗСБ; тектонофизика; Ковыктинское ГКМ

\section{1. ВВЕДЕНИЕ}

В современных условиях сокращения объемов легко извлекаемых запасов углеводородного сырья возрастает необходимость в разработке новых способов картирования структуры платформенного чехла, которые позволят повысить эффективность разведки и эксплуатации месторождений. Одной из структурных составляющих дислоцированности породного массива являются зоны разломов, облада- ющие неоднородной проницаемостью для флюидов и газов. Зоны специфическим образом проявляются в платформенных условиях, что осложняет выделение их границ и особенностей внутреннего строения у поверхности и, тем более, на уровне продуктивных горизонтов.

В соответствии с представлениями тектонофизики [Sherman et al., 1991; Seminsky, 2003] зоны разломов формируются в течение трех последовательных стадий эволюции внутренней структуры 

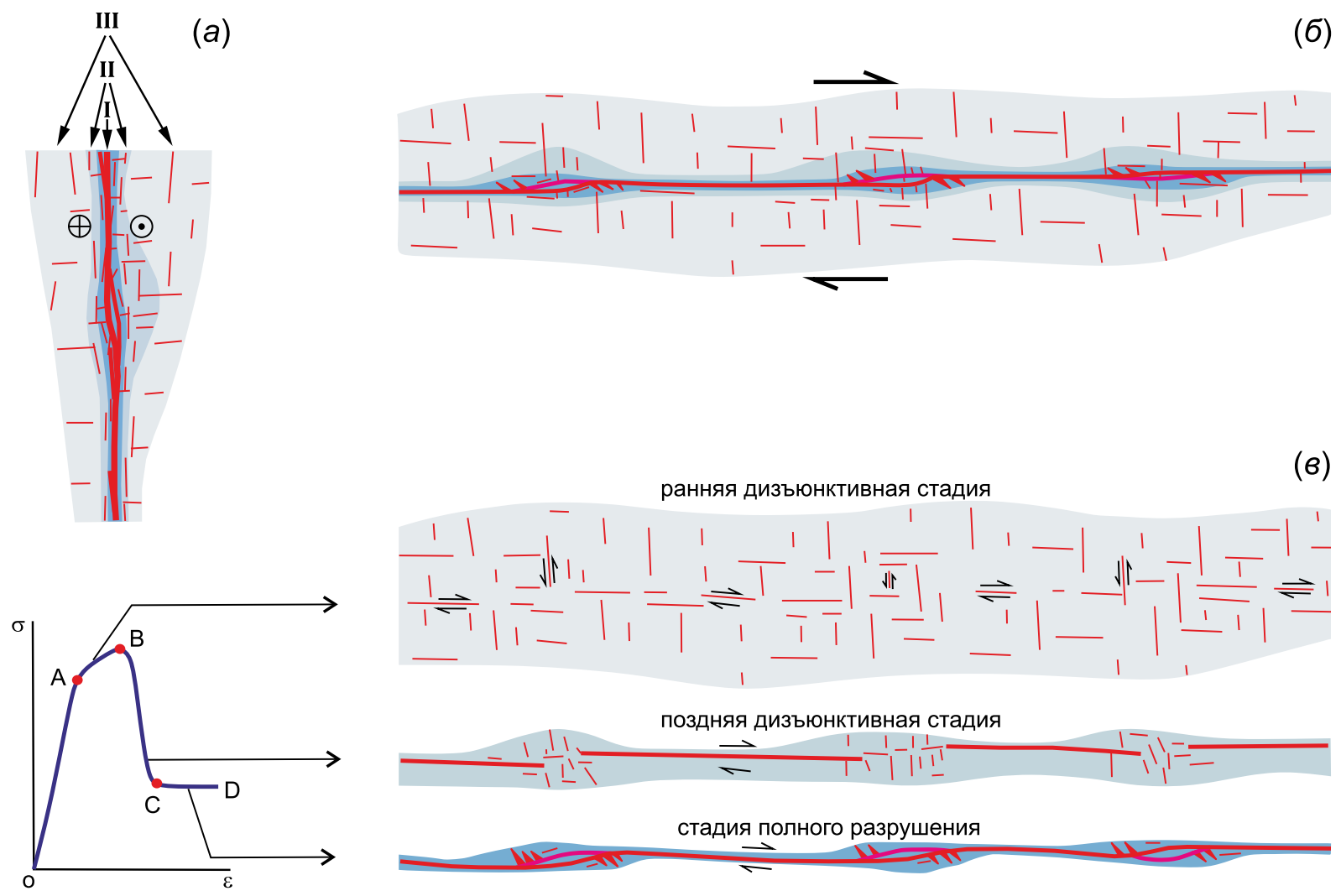

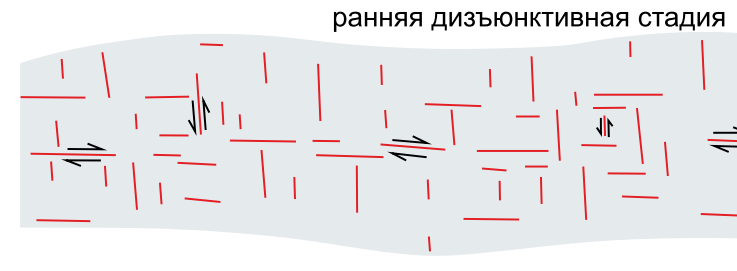

(б)
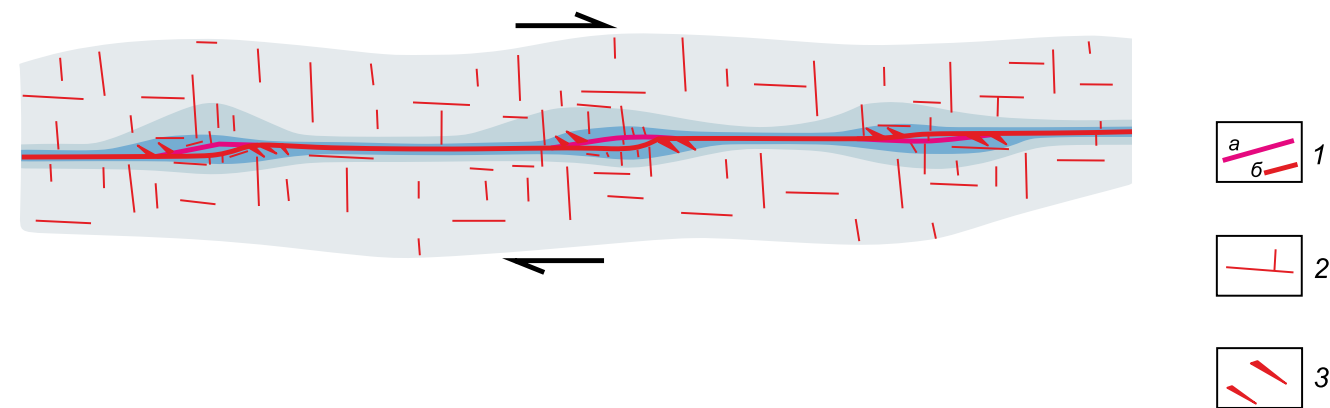

(8)
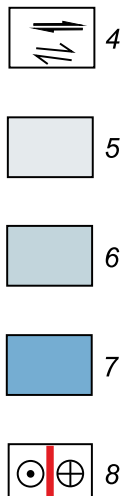

Рис. 1. Тектонофизическая модель зонального строения разломной зоны (на примере правого сдвига).

(a) - поперечная зональность строения разломной зоны как следствие стадийности ее развития (в разрезе): I - подзона главного сместителя 1-го порядка; II - подзона разрывов 2-го порядка и повышенной трещиноватости; III - периферийная подзона парагенетически связанных трещин; (б) - внутренняя структура зоны полностью сформировавшегося разлома (в плане); (в) схемы активных разрывов на трех стадиях разломообразования (в плане), каждой из которых соответствует характерный отрезок кривой нагрузка $(\sigma)$ - деформация $(\varepsilon)$ : $\mathrm{AB}$ - упрочнение, $\mathrm{BC}$ - ослабление, $\mathrm{CD}$ - скольжение блоков по магистральному сместителю.

1 - магистральный сместитель (а) и разрывы 2-го порядка (б); 2 - трещины скола; 3 - трещины отрыва; 4 - характер смещения крыльев по разломной зоне в целом и составляющим ее разрывам; 5 - границы разломной зоны на ранней дизъюнктивной стадии; 6 - то же на поздней дизъюнктивной стадии; 7 - то же на стадии полного разрушения; 8 - направление скольжения крыла сдвига: на наблюдателя (слева) и от наблюдателя (справа).

Fig. 1. Tectonophysical model showing the zonal structure of a right-lateral strike slip fault zone.

(a) - transverse zoning of the fault zone structure, which results from its staged development (cross-section): I - subzone of the main fault plane of the first order; II - subzone of second-order ruptures and increased fracturing; III - peripheral subzone of paragenetically related fractures; (6) - internal structure of the zone of a fully formed fault (plan); ( 8 ) - schemes of active ruptures at the three stages of faulting (plan). For each stage, characteristic segments of the loading $(\sigma)$ - deformation $(\varepsilon)$ curve are as follows: AB - strengthening, BC - weakening, CD - sliding of blocks along the main fault plane.

1 - main fault plane (a) and second-order ruptures (б); 2 - cleavage fractures; 3 - separation fractures; 4 - displacements of the fault wings along the entire fault zone and along ruptures comprising the fault zone; 5-7 - boundaries of the fault zone at the early (5), late (6) and complete destruction (7) stages; 8 - direction of sliding of the fault wing to and from the observer (left and right, respectively).

(рис. 1, 8). В наиболее общем случае это предопределяет наличие у полностью сформированного разлома трехчленной поперечной зональности (рис. 1, $a$, б). Подзона магистрального сместителя, представленная сравнительно узкой полосой тектонитов, находится в осевой части и образуется лишь на самой последней (третьей) стадии разломообразования. От нее по направлению к крыльям распространяется подзона развития оперяющих разрывов 2-го порядка и повышенной трещиноватости, яв- ляющаяся результатом поздней дизъюнктивной стадии разломообразования. Наконец, на периферии разломной зоны имеет место подзона парагенетически связанной трещиноватости, образовавшаяся на ранней дизъюнктивной стадии.

Третья, периферийная, подзона по плотности трещин более резко отличается от подзоны развития разрывов 2-го порядка, чем от слабо нарушенного смежного массива горных пород. Это является причиной того, что в структурной геологии она 
не считается принадлежностью зоны разлома, которая в широко распространенной трактовке [Mikhailov, 1956; Chester, Logan, 1986; Twiss, Moores, 1992; Schulz, Evans, 2000] состоит из подзоны сместителя (core zone) и подзоны вторичных разрывов и трещин (damage zone). Между тем ее выделение в составе разломной зоны имеет принципиальное значение при исследованиях структуры платформенного чехла на предмет выявления закономерностей миграции высокомобильных углеводородов. Вследствие слабой тектонической активности развитие разломной структуры в подобной ситуации, как правило, не достигает стадии полного разрушения с образованием магистрального шва, смещающего слои-маркеры. В этом случае имеет место неоднородная в плане проницаемости зона повышенной трещиноватости и более крупных разрывов, существенная часть которой представлена подзоной парагенетически связанных трещин. Выявление границ и особенностей внутреннего строения такой проницаемой для углеводородов зоны представляет существенную трудность ввиду отсутствия смещений слоев, достаточных для однозначного фиксирования на сейсмических разрезах.

В подобных условиях особую роль играет электроразведка, так как этот метод позволяет фиксировать нарушенные (разломные) зоны, открытые для миграции флюидов и вследствие этого обладающие высокой электрической проводимостью. Применение новых подходов по обработке электроразведочных данных дает возможность в настоящее время успешно выделять разломные зоны [Reiser et al., 2009; Rønning et al., 2014; Misyurkeeva et al., 2018], но проблема картирования закономерностей их внутреннего строения по-прежнему остается актуальной.

Наши предыдущие исследования [Seminsky et al., 2016; Seminsky, Bobrov, 2018] были посвящены решению данной проблемы на основе материалов электротомографии. Их итогом стала разработка тектонофизического подхода к интерпретации материалов зондирования, позволяющего не только формализованно оконтуривать разломную зону, но и выделять границы ее внутренних подзон, сформировавшихся на разных этапах разломообразования. Электротомография относится к малоглубинным методам исследования, с помощью которых можно получить достоверную информацию о строении земной коры лишь в пределах нескольких десятков метров от поверхности. Целью данной работы было апробировать тектонофизический подход к исследованию строения разломных зон на материалах электроразведки методом зондирования становлением поля в ближней зоне (ЗСБ), который обеспечивает получение достоверных данных об электриче- ской проводимости пород осадочного чехла до глубины в несколько километров [Pospeev et al., 2018].

\section{2. ОБЪЕКТЫ ИССЛЕДОВАНИЯ}

Объектом исследований была сеть разломных зон в пределах тестовой площади на северо-востоке Ковыктинского лицензионного участка (ЛУ), где была проведена детальная съемка методом 3СБ (рис. 2). В региональном плане [Staroseltsev, 2005] Ковыктинское газоконденсатное месторождение (ГКМ) располагается в северо-восточной части моноклинального склона Ангаро-Ленской ступени (АЛС), в зоне перехода от Непско-Ботуобинской антеклизы к АЛС и к Предпатомскому региональному прогибу. Осадочный чехол, вмещающий месторождение, по данным сейсморазведки достигает мощности в несколько тысяч метров и включает три формационных комплекса: подсолевой, соленосный и надсолевой.

В составе терригенно-карбонатных пород подсолевого комплекса (рифей - венд - нижний кембрий), залегающего на выветрелой поверхности метаморфизованных пород фундамента, выделяется парфеновский горизонт с основными запасами природного газа. Породы вышележащего солевого (галогенно-карбонатного) комплекса по мощности достигают 1800 м и представлены переслаиванием каменной соли с доломитами, известняками и ангидритами. Надсолевой комплекс сложен терригенно-карбонатными породами среднего - верхнего кембрия и терригенными отложениями ордовика, которые на отдельных участках перекрыты четвертичным аллювием.

Сведения о разломной тектонике осадочного чехла юга Сибирской платформы представлены на картах и в серии публикаций отечественных геологов [Zolotarev, 1967; Zamaraev et al., 1979; Dubrovin, 1979; Zolotarev, Khrenov, 1979; Khrenov, 1982; Logachev, 1984; Malykh, 1985; Seminsky, Gladkov, 1997; Gladkov et al., 2000; Sizykh, 2001; Arzhannikova, Arzhannikov, 2005; Sankov et al., 2017; и дp.]. Они свидетельствуют о существовании в осадочном чехле достаточно редкой сети разрывных нарушений, которая сгущается в пределах Хандинского и Жигаловского валов, располагающихся на востоке и юго-востоке от изучаемой площади.

Разломы, в их традиционном понимании, для участка детальных электроразведочных работ не выявлены. Однако, судя по данным предыдущих исследований [Seminsky et al., 2018], в его пределах установлена сеть разломных структур, находящихся на ранних стадиях формирования (рис. 2). Главным признаком для выделения разломных зон явились сгущения спрямленных элементов релье- 


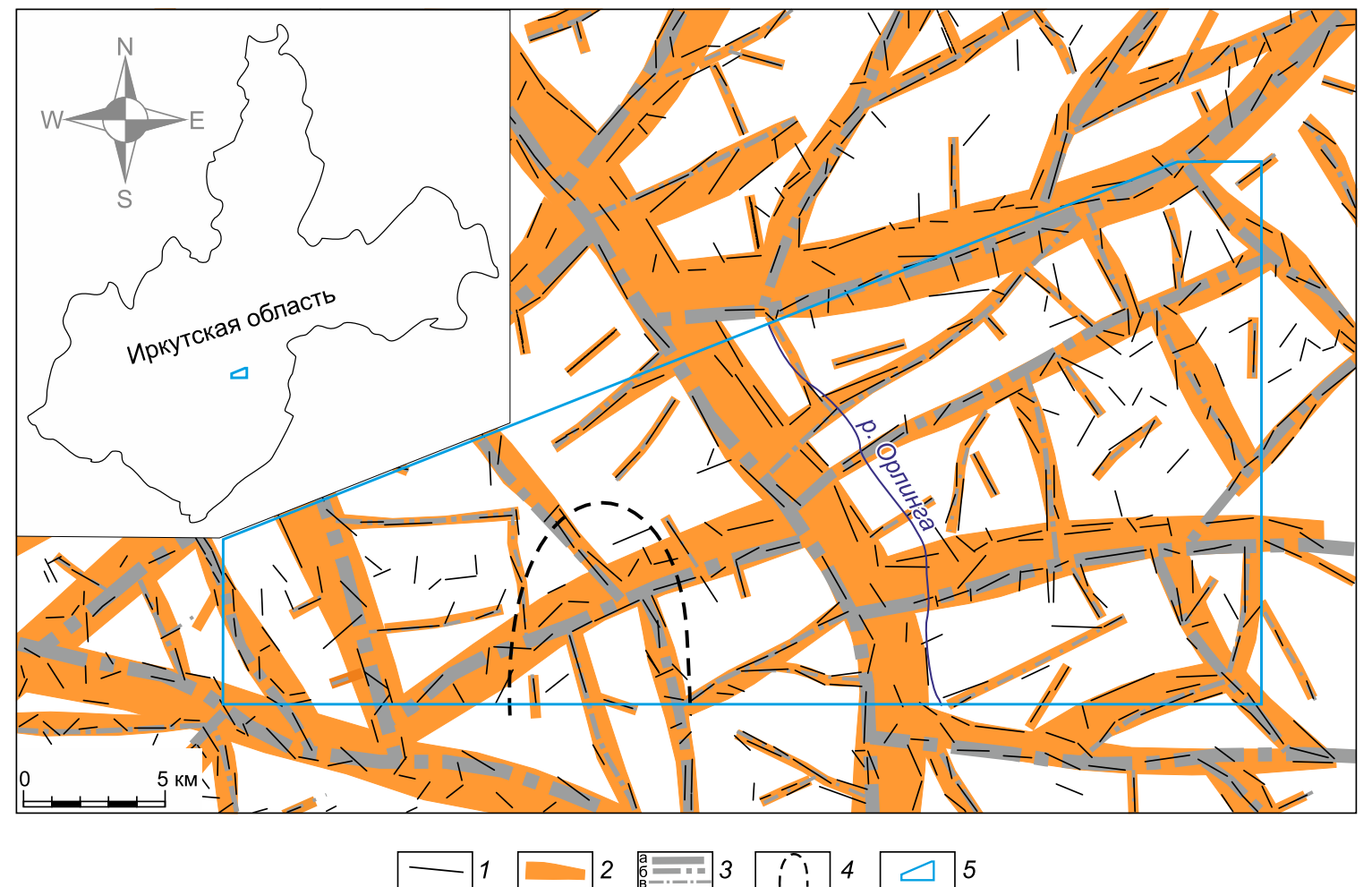

Рис. 2. Схема разломных зон на северо-востоке Ковыктинского лицензионного участка в пределах одноименного газоконденсатного месторождения, построенная по данным линеаментного анализа рельефа.

1 - линеаменты рельефа; 2 - разломные зоны, находящиеся на ранних стадиях развития внутренней структуры; 3 - оси зон 1-го (а), 2-го (б), 3-го (в) масштабного ранга; 4 - граница северной оконечности Большеириньского вала по кровле галогеннокарбонатного комплекса; 5 - контур участка детальных исследований.

Fig. 2. Fault zones in the northeastern part of the Kovykta license area in the Kovykta gas condensate field. The schematic map is based on the lineament analysis of the local relief.

1 - lineaments; 2 - fault zones (their internal structures are at the early stages of development); 3 - axes of the zones of the 1st (a), 2nd (б), 3rd (в) scale ranks; 4 - boundary of the northern end of the Bolsheirinsky berm along the top of the halogen-carbonate complex; 5 contour of the site studied in detail.

фа, которые характеризуются линейной вытянутостью и системным расположением в плане. В платформенных условиях эта особенность является приповерхностным выражением разломной сети, отдельные элементы которой - зоны - не содержат сместителей магистрального типа.

Как видно из рис. 2, сеть разломных структур на площади исследований, по крайней мере в верхней части осадочного чехла, представлена двумя главными системами: северо-западной и северо-восточной. Подчиненное распространение имеют субширотные и субмеридиональные зоны. Следует отметить, что в солевой и подсолевой толще, судя по представленным ранее результатам сейсморазведки [Seminsky et al., 2018], структурная ситуация меняется. В этой части осадочного разреза главной деформационной структурой для северо-востока Ковыктинского ЛУ является Большеириньский вал, который простирается в меридиональном направлении и сопровождается серией субпараллельных разрывов. Северная оконечность вала попадает в пределы площади исследований, что проявляется в области ее южной границы наличием небольших зон сгущения линеаментов рельефа соответствующей ориентировки (рис. 2).

Наиболее крупные из разломных зон участка исследований отражаются и в поле электрической проводимости, изученном методом ЗСБ [Seminsky et al., 2018].

\section{3. МЕТОДЫ ИССЛЕДОВАНИЯ И СПОСОБЫ ПЕРВИЧНОЙ ОБРАБОТКИ ПОЛУЧЕННЫХ ИЗМЕРЕНИЙ}

Электроразведка методом зондирования становлением поля в ближней зоне проводилась на изучаемой территории в модификации 3D ЗСБ. Под 3D ЗСБ авторы понимают выполнение зондирований по высокоплотной сети наблюдений, совмещенной с сетью 3D сейсморазведки. По результа- 
там работ получают объемный куб распределения удельного электрического сопротивления в разрезе осадочного чехла территории исследования. Также в ходе инверсии данных 3D ЗСБ используется ряд специальных процедур и алгоритмов, позволяющих эффективно работать с большими массивами данных [Murzina et al., 2017; Emel'yanov, 2019]. Основу детальных работ, рассматриваемых в статье, представляли оценки продольной электрической проводимости, полученные специалистами АО «Иркутское электроразведочное предприятие» [Gorlov et al., 2016; Il'in et al., 2016; Buddo et al., 2018].

Электроразведочные исследования были выполнены по регулярной высокоплотной сети наблюдений 3D. Длина стороны генераторной петли - 600 м, приёмной - 18 м, сила тока в источнике - до $170 \mathrm{~A}$. Инверсия кривых ЗСБ была проведена в рамках «тонкослоистых» геоэлектрических моделей с закреплением структурного каркаса по данным МОВ ОГТ 3D и бурения [Pospeev et al., 2010; Buddo et al., 2011]. По результатам инверсии получены модели распространения удельного электрического сопротивления (и продольной проводимости) основных горизонтов-коллекторов: келорского, бильчирского, биркинского, атовского, христофоровскобалыхинского, осинского, парфеновского и боханского (рис. 3). Они представляют солевой и подсолевой комплексы, тогда как вышележащая толща не может быть охарактеризована равноценным образом ввиду влияния на результаты зондирований рельефа и других особенностей приповерхностной части осадочного чехла.

Карты электрической проводимости для каждого из горизонтов были построены в изолиниях, уровни которых отличались на одинаковую величину (рис. 3). Даже при таком стандартном изображении полученные распределения свидетельствуют о наличии линейно вытянутых зон повышенной электропроводности. Особенно отчетливо они проявлены для бильчирского горизонта и христофоровско-балыхинского резервуара, в пределах которых уверенно выделяются две ортогональные системы. Одна из них простирается в северо-западном, а другая - в северо-восточном направлении, что характерно и для разломных зон, выявленных посредством линеаментного анализа рельефа (см. рис. 2). Более того, пространственное положение наиболее крупных из них совпадает с линейно вытянутыми участками повышенной электропроводности. Это, прежде всего, относится к разломным зонам, существование которых явилось причиной формирования широких долин р. Орлинга и ее главных притоков.

Отчетливая взаимосвязь участков высокой электропроводности с разломными зонами послужила основанием для апробирования на получен- ных для рассматриваемого участка данных ЗСБ тектонофизического подхода, направленного на формализованное выделение границ разломных зон и особенностей их строения, в частности внутренней зональности.

\section{4. ТЕКТОНОФИЗИЧЕСКИЙ ПОДХОД К ОБРАБОТКЕ И ИНТЕРПРЕТАЦИИ ДАННЫХ ЗСБ}

Обработка материалов ЗСБ проводилась в соответствии с методикой, разработанной на примере данных электротомографии и подробно изложенной в статье [Seminsky et al., 2016].

Как уже упоминалось, подход базируется на тектонофизических представлениях о разломных зонах, трехстадийное формирование которых в верхней части коры предопределяет наличие отчетливой поперечной зональности. От осевой части к крыльям происходит смена подзон, сформировавшихся на стадии полного разрушения (подзона главного сместителя - I), поздней дизъюнктивной стадии (подзона развития разрывов 2-го порядка и повышенной трещиноватости - II) и ранней дизъюнктивной стадии (периферийная подзона парагенетически связанной трещиноватости - III). Подзоны отличаются друг от друга уровнем нарушенности, т.е. густотой разрывов и/или степенью переработки пород за счет их истирания и дробления в процессе блоковых перемещений. Согласно ранее проведенным исследованиям [Seminsky et al., 2016], к этим трем уровням нарушенности в породном массиве, содержащем разломную зону, добавляются еще два, первый из которых отвечает за фоновую трещиноватость, а второй - за блоки, практически не содержащие видимых трещин.

Существование пяти рассматриваемых уровней отражается на гистограмме плотности трещин (D), одна из которых для примера в форме графика показана на рис. $4, a$, и соответствует участку проведения методических работ в Западном Прибайкалье. В пределах каждого из уровней замеры плотности трещин встречаются, не считая отдельных «отскоков», с примерно одинаковой частотой. Уровень III, соответствующий подзоне парагенетически связанной трещиноватости, характеризуется максимальной частотой встречаемости. Четыре других уровня (I, II, IV и V) образуют симметричные пары на каждой из нисходящих ветвей в целом нормального распределения параметра D. Правая ветвь представляет замеры в разломной зоне, а левая - в слабонарушенных породах за ее пределами.

Представленные уровни подобным образом проявляются и на гистограмме значений удельного электрического сопротивления (УЭС, $\rho)$, приведенного на рис. 4,6 , для того же участка. Принципи- 

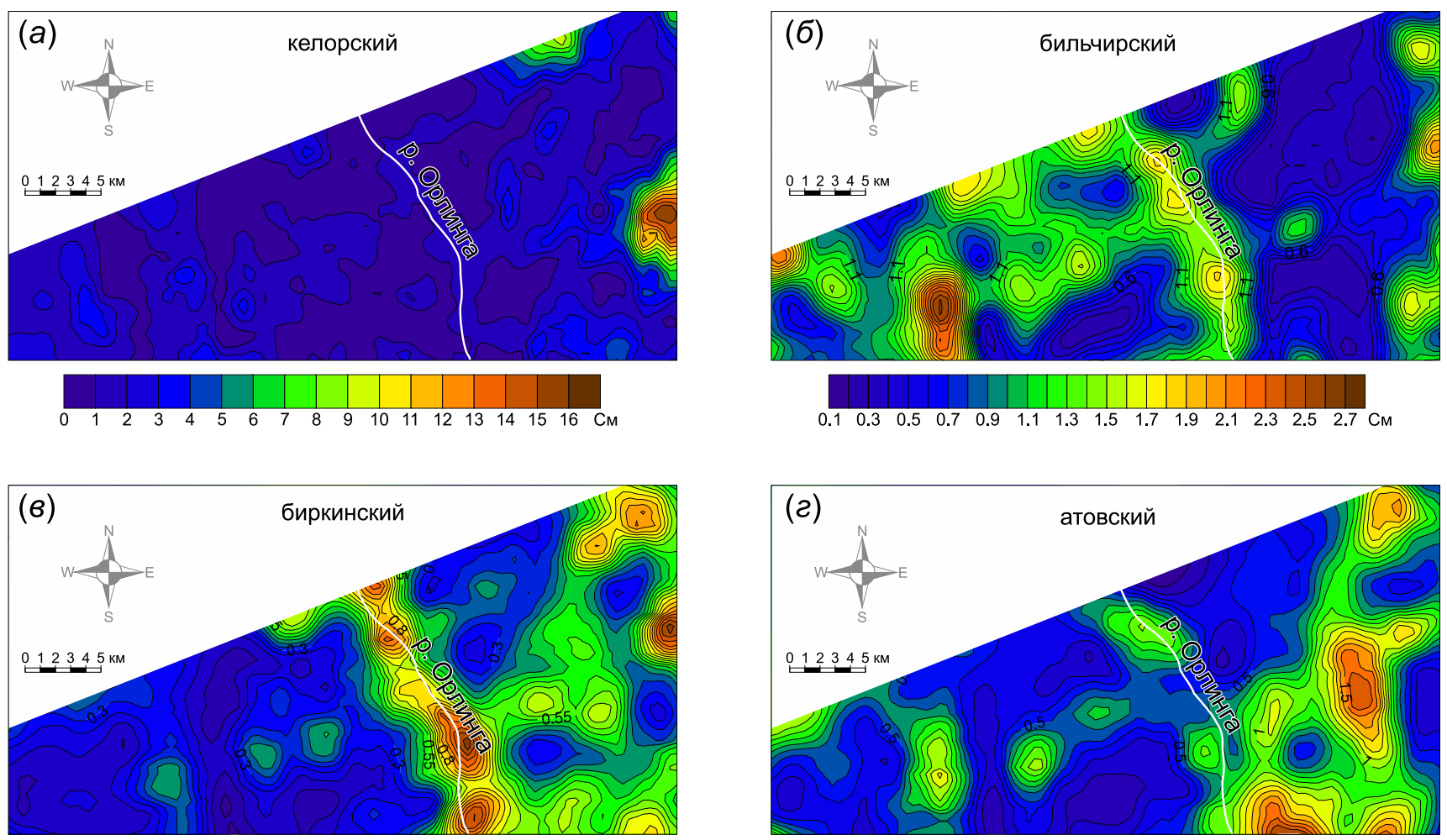

$\begin{array}{llllllllllll}0.05 & 0.15 & 0.25 & 0.35 & 0.45 & 0.55 & 0.65 & 0.75 & 0.85 & 0.95 & 1.05 & 1.15 \\ \mathrm{Cm}\end{array}$
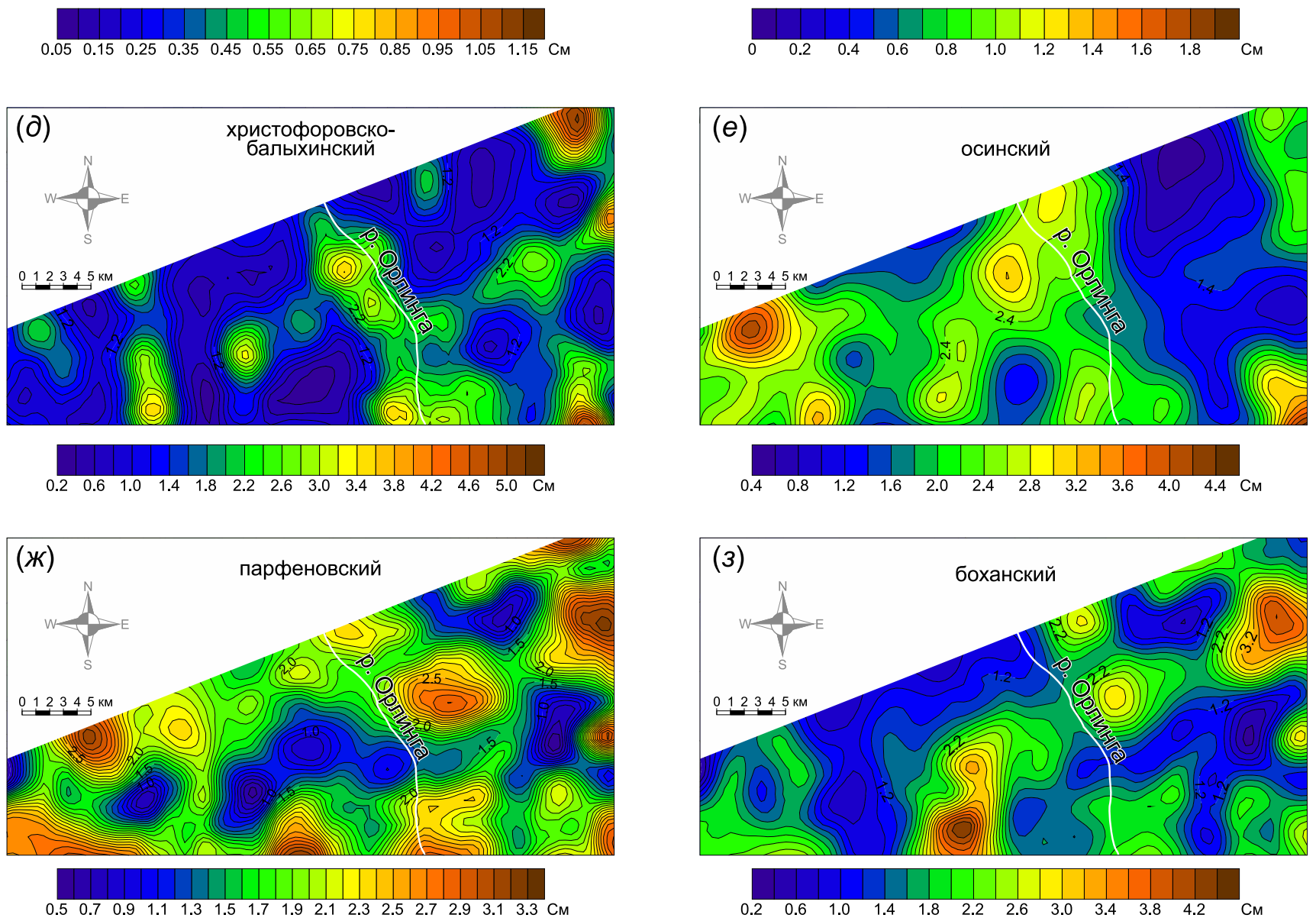

Рис. 3. Карты продольной электропроводности (S, См) келорского (a), бильчирского (б), биркинского ( 8$)$, атовского (2), осинского (e), парфеновского (ж), боханского (3) горизонтов и христофоровско-балыхинского резервуара $(\partial)$ в пределах участка детальных работ ЗСБ, построенные с равномерным сечением изолиний параметра S.

Fig. 3. Maps of longitudinal electrical conductivity (S, Sm) of the Kelor (a), Bilchir (б), Birkin ( 6 ), Atov (2), Osa (e), Parfenov $(\nVdash)$ and Bokhan (3) horizons and the Khristofor-Balykhinsky reservoir $(\partial)$ within the site studied in detail by the TDEM technique. The maps are constructed with the uniform section of parameter $\mathrm{S}$ isolines. 

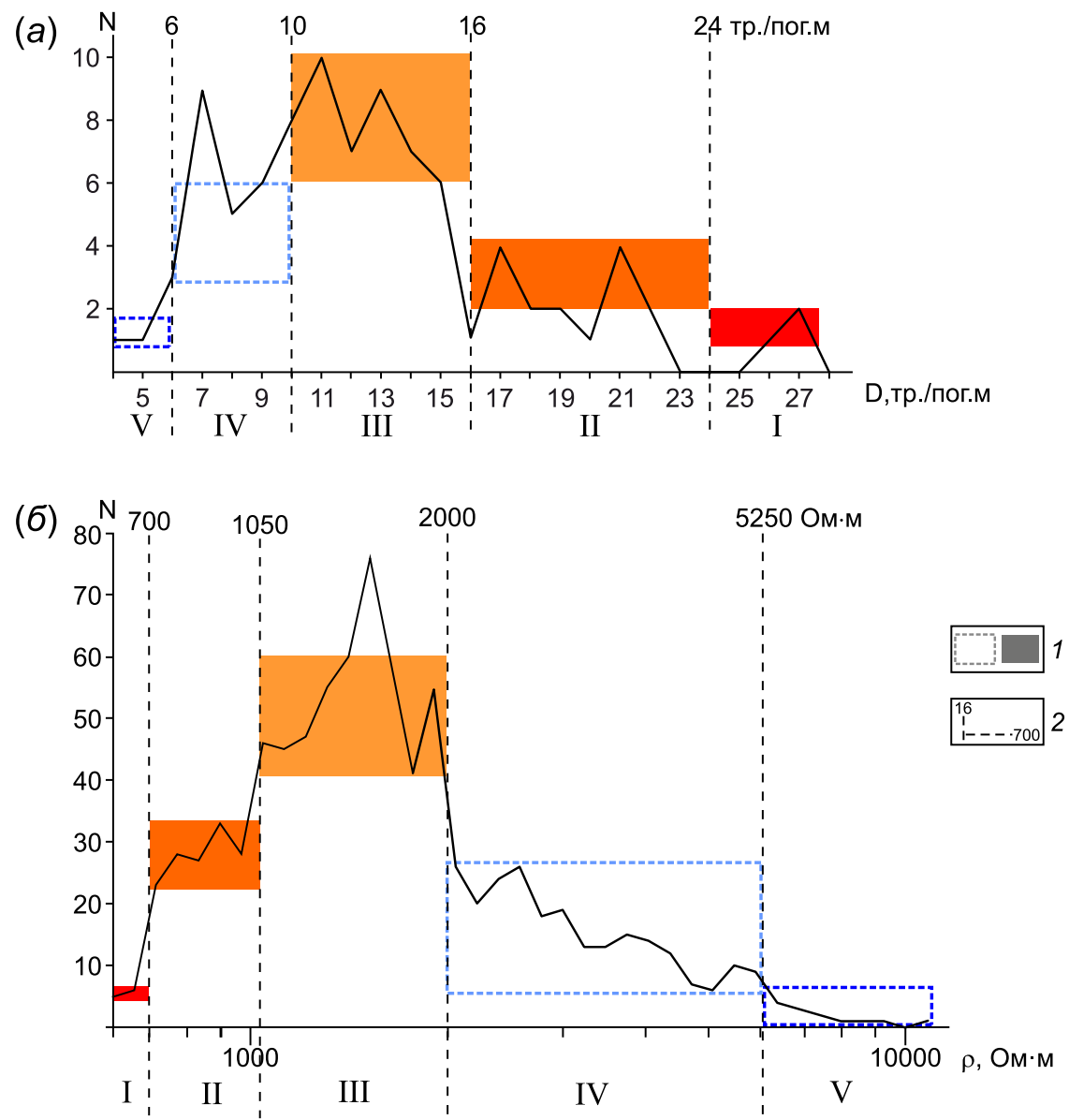

Рис. 4. Гистограммы, иллюстрирующие наличие для одного из нарушенных разломом скальных массивов Западного Прибайкалья (мыс Онтхой, Приольхонье) пяти уровней значений плотности трещин (D) (a) и удельного электрического сопротивления ( $\rho)(б)$.

1 - фрагменты графиков с сериями близких по частоте встречаемости (N) значений D или $\rho$; 2 - границы фрагментов, соответствующих пяти (I-V) состояниям нарушенности породного массива, которые закономерно отличаются пределами изменений параметров D или $\rho$ вследствие постадийного формирования разломной зоны. Цветом отмечены разные уровни значений D или $\rho$, выделяющиеся на гистограммах.

Fig. 4. Histograms for a rock mass disturbed by a fault (Cape Ontkhoi in the Olkhon area, West Pribaikalie). The histograms illustrate the five levels of fracture density (D) $(a)$ and electrical resistivity ( $\rho)(\sigma)$.

1 - fragments of graphs with series of D or $\rho$ values that are close in the frequency of occurrence (N); 2 - boundaries of fragments corresponding to the five (I-V) states of disturbance of the rock mass, which show regularly different limits of changes in parameter D or $\rho$ due to the staged development of the fault zone. Colours indicate different levels of D or $\rho$ values specified in the histograms.

альный вид графика сохраняется, но разломной зоне соответствует его левая часть, а массиву с фоновой трещиноватостью - правая, поскольку УЭС пород связана со степенью их нарушенности разрывами обратной зависимостью. Для Западного Прибайкалья это было установлено путем прямого коррелирования параметров D и $\rho$ [Seminsky, Zaripov, 2016], а также сопоставления их гистограмм по нескольким тестовым площадкам, для которых форма распределений в качественном отношении была подобной при различии в абсолютных значениях пяти выделяющихся уровней.

Следствием представленной выше закономерности стало формирование методического подхода, позволяющего использовать данные электроразведки для оконтуривания разломных зон и выделения подзон в их пределах [Seminsky et al., 2016; Seminsky, Bobrov, 2018]. Он был успешно апробирован на материалах малоглубинной электротомографии и заключается в построении и анализе гистограммы распределения параметра $\rho$ с выделением пяти уровней нарушенности субстрата, а затем - в определении соответствующих им участков породного массива на геоэлектрическом разрезе. Ниже представлены результаты применения подобного методического приема для площади детальных работ ЗСБ в пределах Ковыктинского ЛУ. Развитие нового подхода в данном случае заключа- 
ется в том, что построения проводились для нескольких горизонтов субгоризонтально залегающей осадочной толщи, и в качестве оценочного параметра использовалась продольная электрическая проводимость массива горных пород (S).

Специфика базового материала потребовала корректировки способа определения уровня параметра $\mathrm{S}$, соответствующего внешней границе разломной зоны (рис. 5). При работе с данными электротоморафии разломных зон Западного Прибайкалья этим значением была величина УЭС, ограничивающая справа центральный максимум на гистограмме (см. рис. 4, б). Действительно, наиболее часто в массиве величин $\rho$ встречались те значения, которые соответствуют периферийной зоне парагенетически связанной трещиноватости, так как профили электротомографии далеко не заходили в слабонарушенный массив за ее внешними границами. В случае участка исследований на Ковыктинском ГКМ анализируется существенный объем платформенной толщи, в которой разломные зоны, развивающиеся в условиях сравнительно слабой тектонической активности, не могут превалировать над пространствами с фоновой трещиноватостью.

Таким образом, пограничное для разломной зоны значение параметра $\mathrm{S}$ должно находиться не с краю, а внутри области центрального максимума на анализируемых гистограммах (рис. 5). Выбор критерия для определения рассматриваемого рубежа на данном этапе исследований не может считаться окончательным. Подобная задача при отсутствии твердо установленных границ разломной зоны для какого-либо из объектов изучаемого участка (тем более - на глубине) в принципе не является корректной. Однако предварительное решение может быть принято, исходя из анализа формы центральных максимумов, имеющих место на гистограммах, построенных для отдельных горизонтов-коллекторов.

Судя по рис. 5, центральные части гистограмм имеют различный вид, но в некоторых случаях они состоят только из двух максимумов 2-го порядка (рис. $5, \partial ; 5, e-3$ ), т.е. граница разломной зоны может быть проведена по значению $\mathrm{S}$ в области разделяющего их минимума. В других случаях из нескольких частных максимумов центральной части графика выделяется тот, который следует сразу за участком, отвечающим за электропроводность пород в подзоне разрывов 2-го порядка и повышенной трещиноватости (II). Таким образом, он заведомо характеризует разломную зону и может отвечать за электропроводность пород в пределах периферийной подзоны парагенетически связанной трещиноватости (III).

Использование данного критерия для выделения внешней границы разломных зон в совокупно- сти с отработанным ранее подходом [Seminsky et al., 2016; Seminsky, Bobrov, 2018] к определению уровней нарушенности пород в подзонах I и II позволило построить для каждого из горизонтов-коллекторов новые варианты карт продольной электрической проводимости (рис. 5). Области, отличающиеся высоким уровнем нарушенности, показаны на них оттенками оранжевого цвета и характеризуются закономерными пространственными взаимоотношениями, описанию которых посвящен следующий раздел статьи.

\section{5. СЕТЬ РАЗЛОМНЫХ ЗОН СЕВЕРО-ВОСТОЧНОЙ ЧАСТИ КОВЫКТИНСКОГО ЛУ ПО ДАННЫМ ПРИМЕНЕНИЯ ТЕКТОНОФИЗИЧЕСКОГО ПОДХОДА К ОБРАБОТКЕ МАТЕРИАЛОВ ЗСБ}

Карты параметра S, построенные для отдельных горизонтов-коллекторов с выделенными по гистограммам уровнями изолиний (рис. 5), характеризуются общими особенностями распределения электропроводности. Области низких значений $\mathrm{S}$ занимают большую часть изучаемой площади и в основном отличаются изометричной формой, что позволяет отождествлять их со слабонарушенными блоками. Высокие значения электропроводности концентрируются в сравнительно узких полосах, которые могут быть сгруппированы в однонаправленные системы. Это подтверждает их разломное происхождение и ту роль, которую они, как проницаемые каналы, играют в миграции через толщу осадков флюидов и газов.

Сопоставление положения осей зон повышенной электропроводности на разной глубине дает возможность выделить сеть из восьми структур, проявляющихся более чем в одном горизонте (рис. 5). Практически все эти структуры находят отражение в виде наиболее крупных зон, выявленных в ходе линеаментного анализа рельефа (см. рис. 2), что позволяет предполагать их присутствие в пределах большей части осадочного чехла. Вместе с тем, отчетливо видно, что состояние внутренней структуры отдельных разломных зон существенным образом отличается на разных глубинных уровнях и, особенно, в солевом и подсолевом комплексах.

В целом нарушенность субстрата отдельных разломных зон характеризуется неравномерностью не только в поперечном, но и в продольном направлении - по простиранию и падению дизъюнктива (рис. 5). Так в поле распределения электропроводности проявляется одна из наиболее важных закономерностей строения разломных структур [Lobatskaya, 1987; Seminsky, 2003]. Неоднородность нарушенности затрудняет определение 

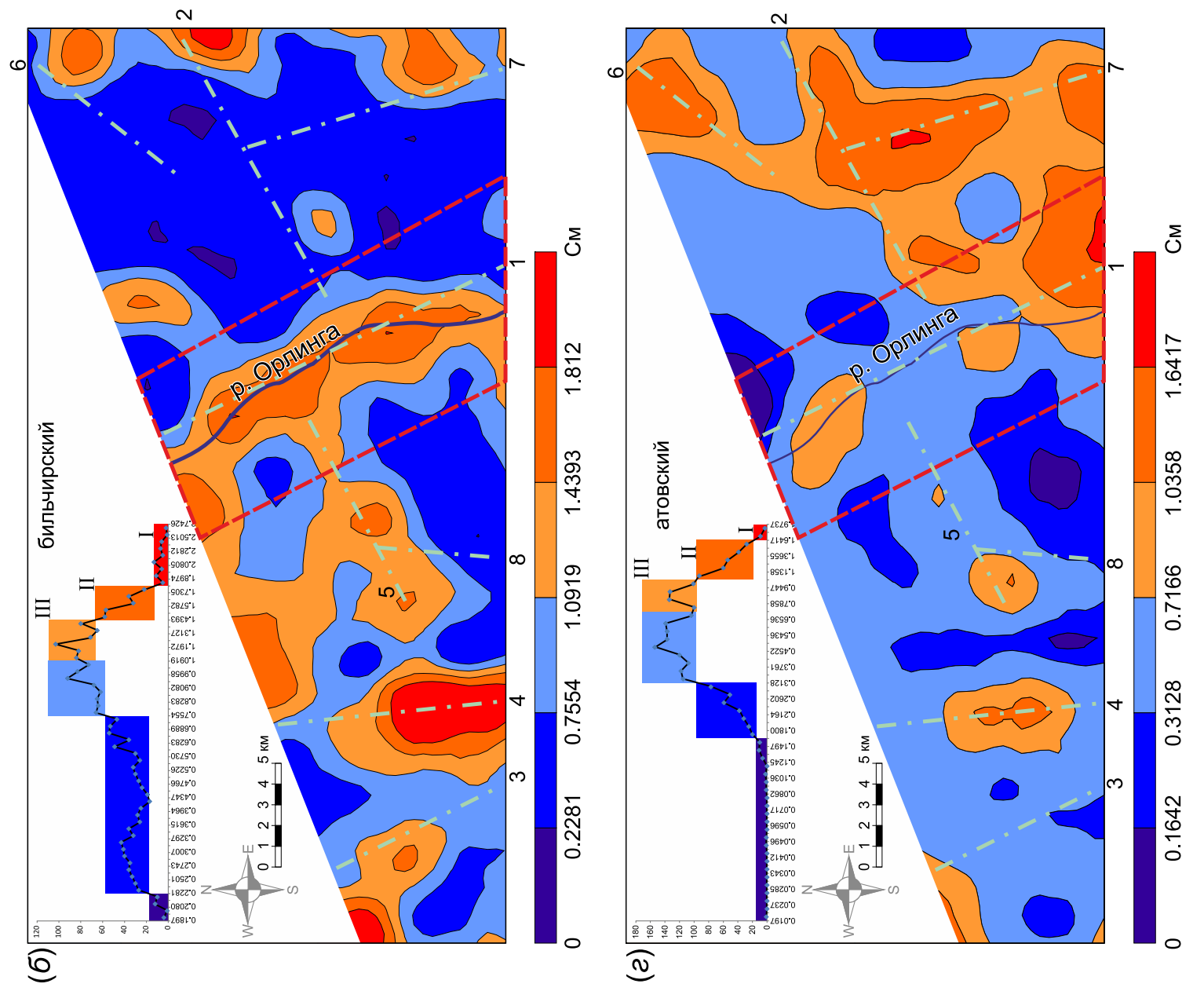

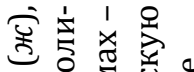

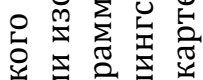

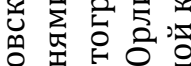

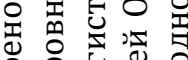

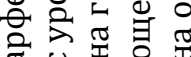

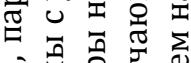

(ิ)

은

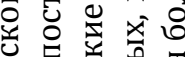

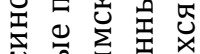

享䎡苜

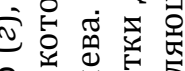

운 55

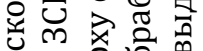

ㄴㅇㅇ 융

$\sigma$ 些

क्⿹勹巳

엄

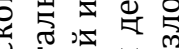

可

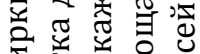

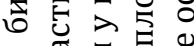

ف닺

을

要

음
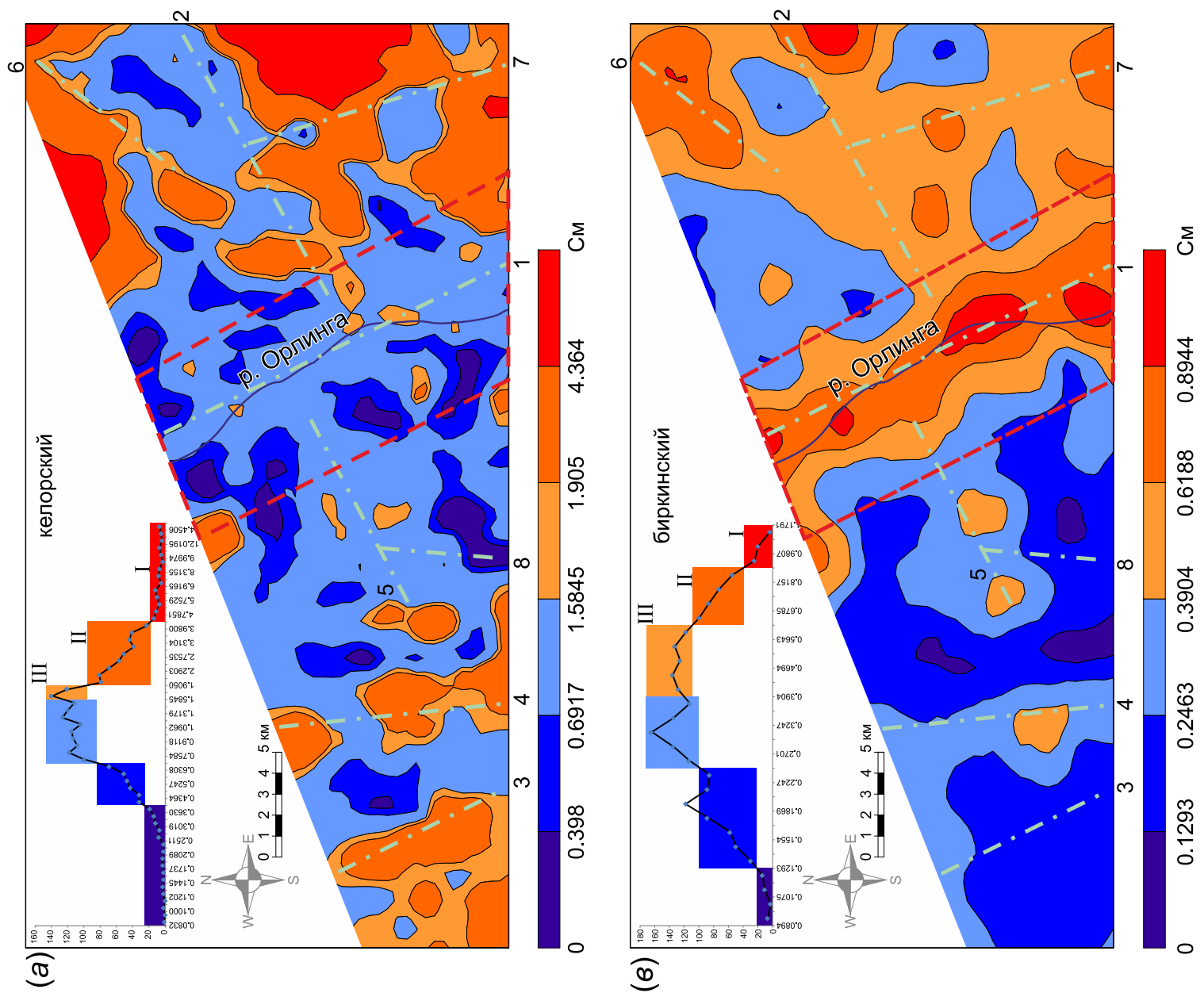

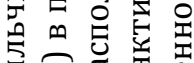

ฮิ

के

익

원

政

잉

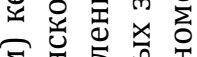

ह

心

究 䒕

둥

이 $5 x$

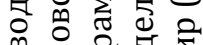

융 융

항

항

可密

5

要

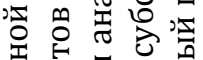

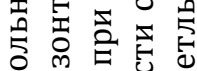

용

을 군

읍을 정

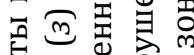

产 잉 5

的空

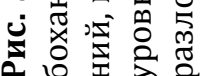



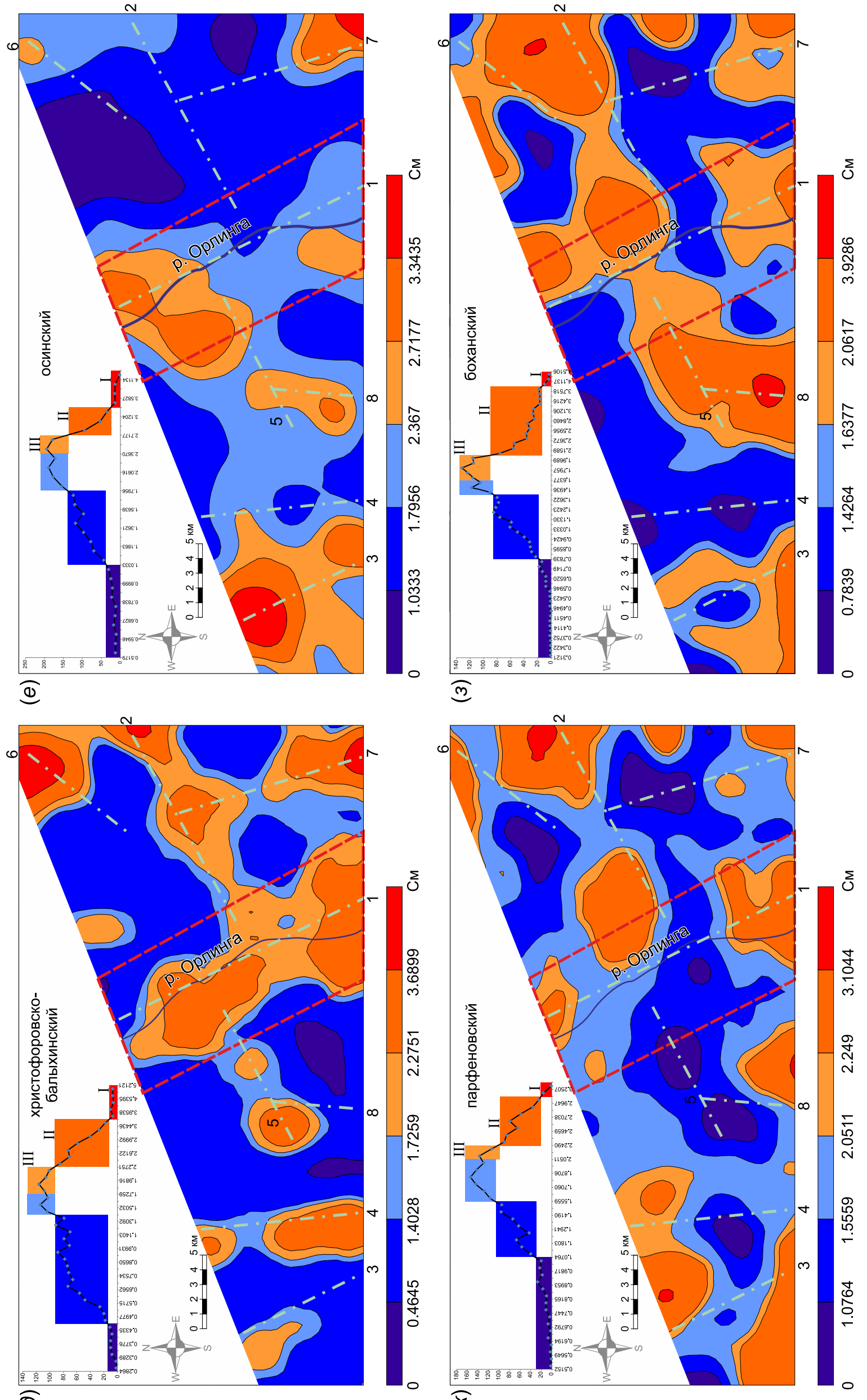

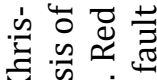

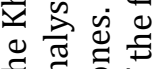

중

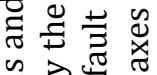

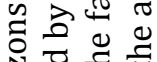

证

올

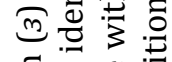

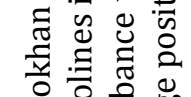

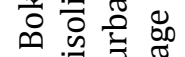

चี

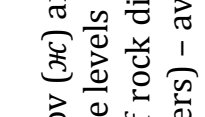

它出

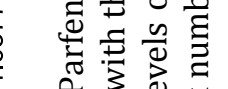

23 更

(2) $1 \frac{\pi}{0}$

苋昰要

(ง)

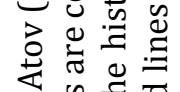

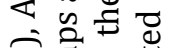

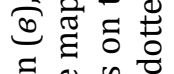

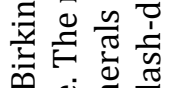

๑)

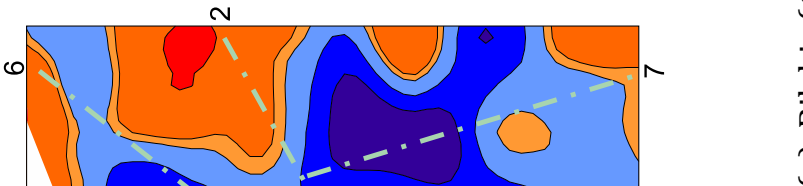

$\because$ 든

可 $\sum_{i=0}^{\infty}$

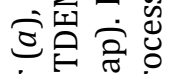

흘

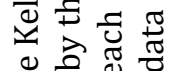

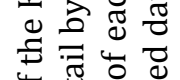

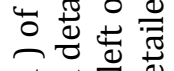

ติ $\Xi$ оㅇ

苍

实施密

总施

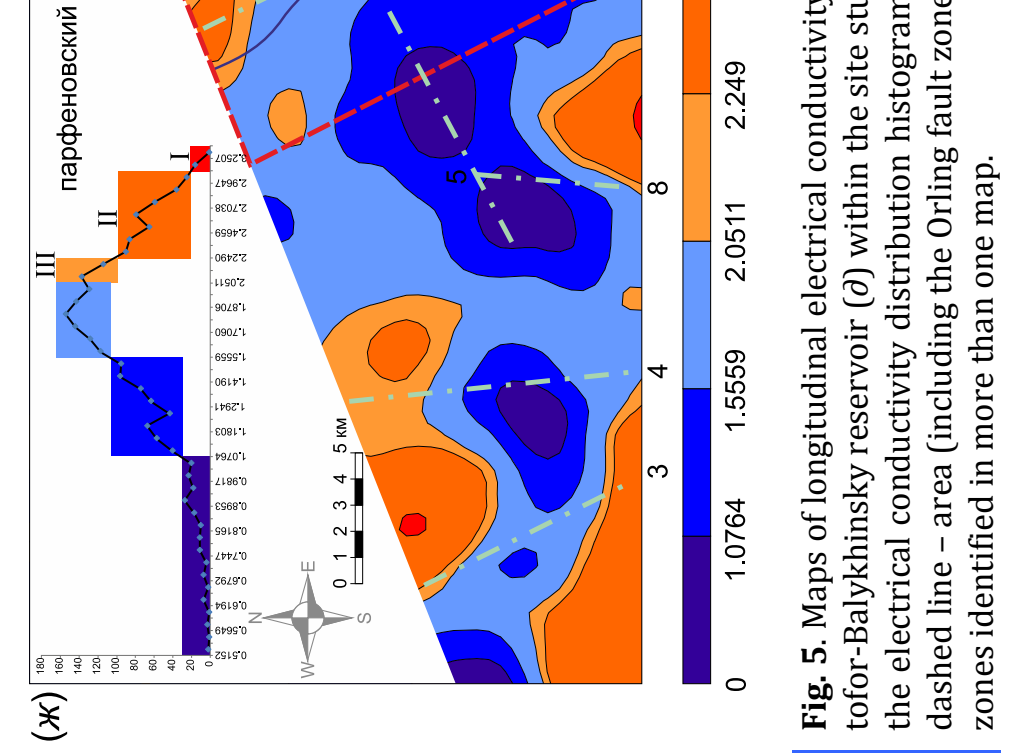



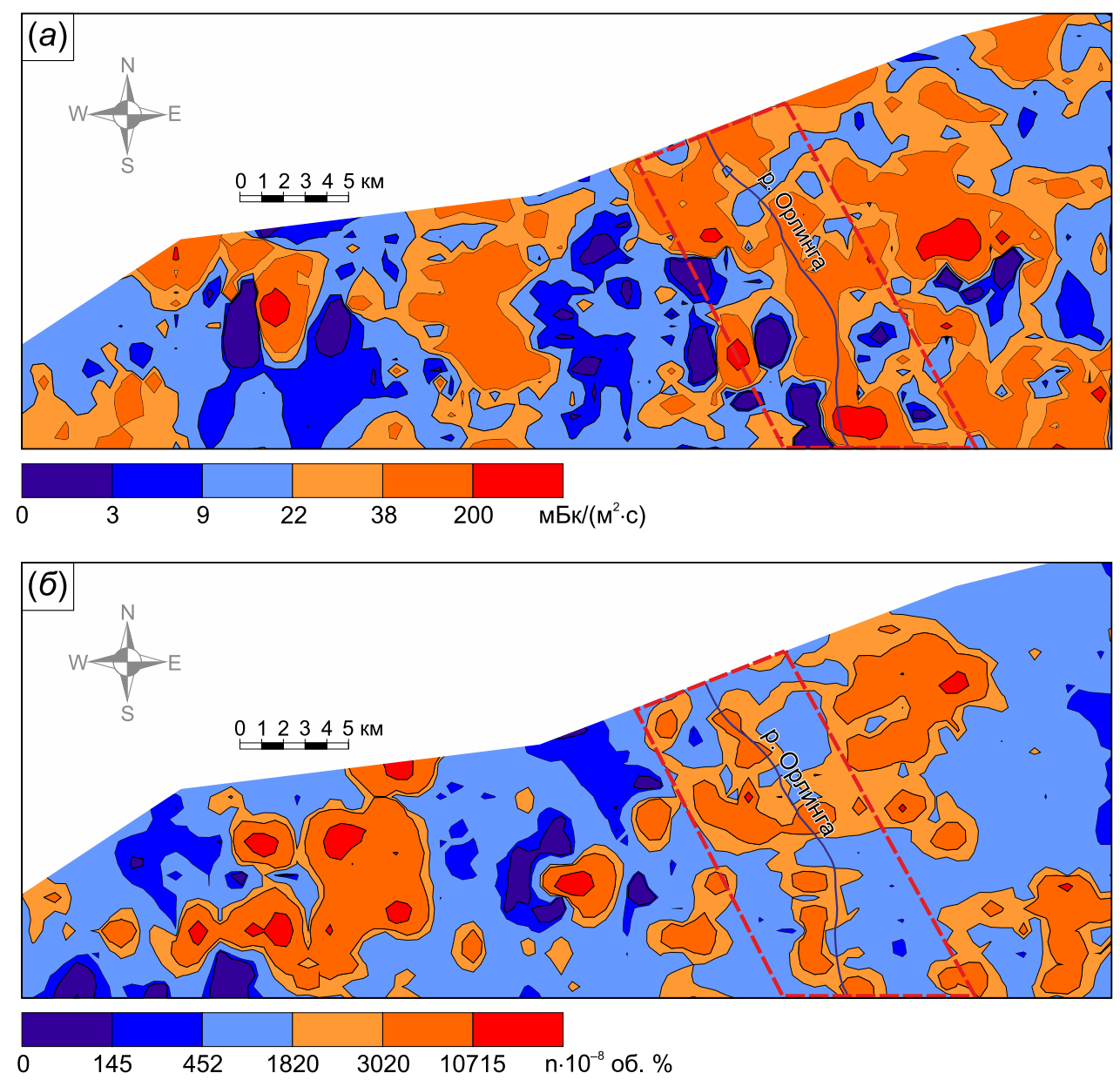

Рис. 6. Карты распределения значений плотности потока радона (a) и содержания пропана (б), построенные для северо-восточной части Ковыктинского ЛУ по данным газогеохимической съемки приповерхностных отложений (материалы 000 «НПЦ Геосфера+»).

Fig. 6. Distribution of radon density (a) and propane concentrations (б) in the northeastern part of the Kovykta license area. The maps are based on the gas-geochemical survey data on subsurface deposits (materials of LLC SPC Geosphere+).

стадии развития дизъюнктивов, выделенных на участке исследований. Можно лишь констатировать, что в целом ни один из них полностью не сформировался: породы, уровень электропроводности которых соответствует стадии полного разрушения (I), локализуются (в случае наличия) на отдельных участках зон, не имея сплошного распространения вдоль их простирания.

Следовательно, в первом приближении структура зон соответствует поздней дизъюнктивной стадии развития (уровень II) и, таким образом, должна быть представлена сгущением разрывов 2-го порядка, развитие которых в процессе структурной эволюции предшествует появлению магистрального сместителя. Для его формирования внешнее воздействие на осадочную толщу должно быть более длительным и/или интенсивным, что, как правило, не характерно для деформации коры в платформенных условиях. При этом на разных глубинных уровнях участки со вторым уровнем нарушен- ности не имеют сплошного распространения, а чередуются по простиранию или/и падению с сегментами, в которых состояние структуры, судя по уровню электропроводности (III), должно соответствовать ранней стадии разломообразования.

Эта широко распространенная ситуация иллюстрируется ниже на примере разломной зоны 1, проходящей по долине р. Орлинга. Зона является наиболее удобным примером, так как, пересекая всю центральную часть площади исследования, в том или ином виде выражена во многих рассматриваемых горизонтах. Кроме того, результаты газогеохимической съемки, проведенной на Ковыктинском ЛУ специалистами 000 «НПЦ Геосфера+» (рис. 6), во-первых, подтверждают ее разломное происхождение и, во-вторых, контролирующую роль в отношении миграции углеводородов.

Действительно, в пределах зоны 1 имеют место повышенные концентрации пропана в почвенном воздухе, а также максимумы плотности потока ра- 
дона с земной поверхности (рис. 6). Повышенный выход радона из недр - известный признак наличия проницаемой зоны, ставший основанием для применения эманационного метода в целях выявления разломных структур, скрытых под рыхлыми наносами [Panov et al., 1984; Ball et al., 1991; Ciotoli et al., 1999; Tansi et al., 2005; Lombardi, Voltattorni, 2010; Walia et al., 2010; и мн. дp.]. Несмотря на небольшой период полураспада (3.82 сут), не позволяющий радиоактивному газу мигрировать на большое расстояние, его линеаризованные аномалии маркируют зоны разломов, проникающих в недра Земли на десятки километров. Это объясняется тем, что подобные структуры являются путями миграции для природных газов, поднимающихся из глубоких горизонтов земной коры, к которым вблизи поверхности присоединяется и радон. В качестве таких карьерных для радона - газов выделяются углерод, азот, водород, метан и другие [Etiope, Martinelli, 2002; Elío et al., 2015; Yuce et al., 2017; Kumar et al., 2018; Shuleikin, 2018; Yang et al., 2003].

Результаты газогеохимической съемки на Ковыктинском ЛУ позволяют предположить (рис. 6), что разломная зона реки Орлинга является каналом для подъема углеводородов (в частности, пропана) из глубоких горизонтов чехла, а радон обогащает газовую колонну у поверхности. Таким образом, детализация внутренней (в т.ч. и глубинной) структуры разломных зон имеет существенное практическое значение для Ковыктинского ГКМ. Рассматриваемый в статье подход позволяет, используя данные детальной электроразведки, строить трехмерные модели дизъюнктивных структур, подобные представленной ниже для разломной зоны 1 (рис. 7).

Наиболее отчетливо разломная зона 1 проявлена в центральной части галогенно-карбонатного комплекса (рис. 7). В пределах бильчирского и биркинского горизонтов это единая и широкая (до 4 км) зона, причем на всем ее протяжении нарушенность породного массива соответствует поздней дизъюнктивной стадии развития (желтый цвет). В пределах биркинского горизонта (и небольшого участка в бильчирском горизонте) имеют место максимумы электропроводности, соответствующие наиболее высокому уровню (I) нарушенности пород в разломной зоне (красный цвет). Наличие таких участков свидетельствует о том, что в их пределах могли сформироваться сегменты будущего магистрального сместителя (см. рис. 1, в, схема для стадии II). В нижележащем атовском горизонте вытянутость изолиний электропроводности вдоль зоны сохраняется, но участки, в пределах которых степень нарушенности пород достигает разломной, пространственно разобщены (рис. 7, пустое пространство в 3D модели). Вероятно, они отражают положение отдельных сравнительно мелких раз- рывных структур, являющихся опережающими [Seminsky, 2003] по отношению к формированию разломной зоны 1 в пределах рассматриваемого участка осадочного разреза. Данное предположение справедливо, так как в нижележащем христофоровско-балыхинском резервуаре зона не только вновь представляет единое целое, но и характеризуется наибольшими поперечными размерами. В осинском горизонте и в показанных на рис. 5 слоях подсолевого комплекса зона 1 представлена подобно атовскому слою, т.е. фрагментарно. В верхнем из рассматриваемых здесь горизонтов - келорском - зона формально отсутствует, но на поверхности она отчетливо выражена сгущением линеаментов рельефа (см. рис. 2), а также повышенным содержанием пропана и радона в почвенном воздухе (см. рис. 6).

Таким образом, на примере рассмотренной трехмерной модели можно заключить, что в условиях горизонтально-слоистого платформенного чехла субвертикальные разломные зоны по внутреннему строению представлены крайне неравномерно. По данным тектонофизической обработки материалов ЗСБ для зоны 1 на разных глубинных уровнях установлен полный набор стадий разломообразования, хотя финальная стадия полного разрушения представлена на двух небольших участках. При этом отсутствует однонаправленная тенденция их закономерной смены в разрезе осадочного чехла, что предполагается исходя из данных моделирования разломных зон, формирующихся над единой плоскостью сместителя в фундаменте [Sherman et al., 1983; Sylvester, 1984; Seminsky, 2003]. Это позволяет считать реологическую расслоенность осадочного разреза на Ковыктинском ГКМ главной причиной неоднородного строения разломных зон. В зависимости от степени компетентности слоев по отношению к разрывообразованию в вертикальном сечении разломной зоны могут чередоваться фрагменты с менее и более зрелой внутренней структурой. Это может, даже без наличия на лицензионном участке явно выраженных разломных сместителей, существенным образом затруднять процесс разведки и эксплуатации месторождения углеводородов.

Трехмерные модели крупных разломных зон, созданные посредством тектонофизического подхода к обработке и интерпретации данных электроразведки методом ЗСБ, являются дополнительной основой для принятия решений о местах строительства скважин и способах разбуривания сложнодислоцированной горизонтально-слоистой осадочной толщи. Так, при бурении разведочных скважин необходимо избегать пересечения горной выработки с участками разломной зоны, представленными породами, степень дислоцированности которых соответствует стадии полного разруше- 


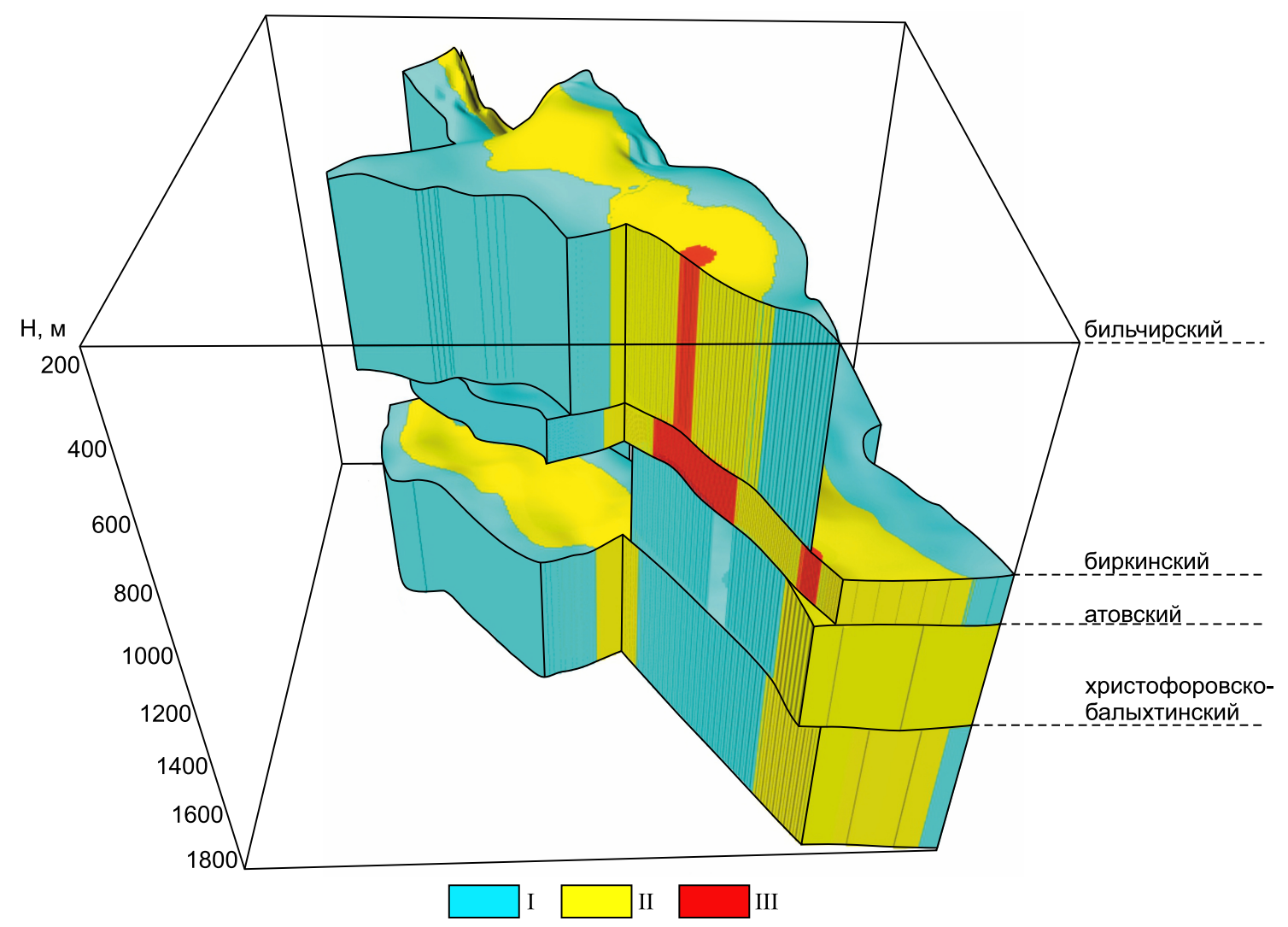

Рис. 7. 3D модель внутреннего строения Орлингской разломной зоны, построенная на основе распределений электропроводности в пределах отдельных горизонтов осадочной толщи на северо-востоке Ковыктинского ЛУ (передняя четверть вырезана для обзора внутреннего строения зоны). I-III - подзоны: парагенетически связанной трещиноватости (III), разрывов 2-го порядка и повышенной трещиноватости (II), главного сместителя (I).

Fig. 7. The 3D model of the internal structure of the Orling fault zone, based on the electrical conductivity distribution within individual horizons of the sedimentary stratum in the northeastern part of the Kovykta license area (the front quarter shows the internal structure of the zone). I-III - subzones of paragenetically related fracturing (III), second-order fractures and increased fracturing (II) and the main fault plane (I).

ния (красный цвет на рис. 5 и 7). Они отличаются сложным напряженно-деформированным состоянием, в котором вероятность проявления аномальных пластовых давлений резко возрастает, т.е. процесс бурения слабопредсказуем.

Трехмерные модели разломных зон, а в перспективе - их полной сети в пределах разрабатываемого объема осадочной толщи, представляют важную составляющую для принятия решения о способе эксплуатации месторождения углеводородов. В нефтяной отрасли знания о зональном строении разломных зон используют для проектирования системы нагнетательных и добывающих скважин [Volpin et al., 2018]. Первые из них размещают в слабонарушенных блоках, а вторые - в пределах подзоны разрывов 2-го порядка и повышенной трещиноватости (в принятой здесь терминологии), где приток нефти является устойчивым по сравнению с подзоной магистрального сместителя и более интенсивным по отношению к подзоне парагенетически связанной трещиноватости. Разработка путей использования зонального строения разломов при эксплуатации газоконденсатных месторождений - тема будущих исследований, методической базой которых, в частности, являются подходы, представленные в статье.

\section{6. ЗАКЛЮЧЕНИЕ}

Материалы электроразведки методом ЗСБ, полученные для небольшой площади в пределах Ковыктинского газоконденсатного месторождения (Восточная Сибирь), были обработаны и интерпретированы с позиций тектонофизических представлений о поперечно-зональном строении разломов, формирующемся в течение трех последовательных стадий: ранней дизъюнктивной, поздней дизъюнктивной и стадии полного разрушения. Это обогатило данный подход, апробированный ранее при анализе геоэлектрических разрезов электротомографии [Seminsky et al., 2016; Seminsky, Bobrov, 2018], за 
счет возможности картирования разломных зон в поле электрической проводимости пород на разных глубинных уровнях платформенного чехла, в т.ч. и с помощью построения их трехмерных моделей.

Для участка детальных ЗСБ на северо-востоке Ковыктинского ЛУ была установлена сеть разломных зон, которые проявлены в пределах отдельных горизонтов-коллекторов в виде линейно вытянутых областей, отличающихся высокой электропроводностью в связи с повышенной проницаемостью для флюидов и газов. Величины электропроводности, обусловленные степенью нарушенности пород в разломных зонах, свидетельствуют о том, что в целом они не достигли в своем развитии заключительной стадии полного разрушения, когда сформирована поверхность единого сместителя. Это зоны повышенной трещиноватости и сгущения разрывов 2-го порядка, характерные для платформ ввиду их относительно слабой тектонической активности.

Пространственное распределение электропроводности разломных зон Ковыктинского ЛУ отличается крайней неравномерностью не только в поперечном, но и в продольном направлении. Вариации параметра по простиранию разломной структуры обусловлены известной неравномерностью распределения деформаций, которая в данном случае выражается в чередовании максимумов и минимумов плотности трещин и разрывов 2-го порядка.

Структурная неоднородность разломных зон в вертикальном разрезе, обусловливающая вариации электропроводности по их падению, на Ковыктинском ГКМ связана, прежде всего, с реологической расслоенностью осадочного чехла. На примере крупной разломной зоны по р. Орлинга было показано, что степень зрелости ее внутренней структуры не меняется последовательно при переходе от более глубоких горизонтов к менее глубоким. В реологически менее компетентном слое зона представлена фрагментарно (например, атовский горизонт), тогда как в соседних слоях (нижнем - христофоровско-балыхинском и верхнем - биркинском) ее строение соответствует поздней дизъюнктивной стадии развития.

Структурная неоднородность подобного типа является осложняющим фактором при разведке и эксплуатации месторождений углеводородного сырья, так как существенно меняет напряженное состояние осадочной толщи, приводя к слабо предсказуемым проявлениям аномальных пластовых давлений. Обработка данных электроразведки посредством рассмотренных в статье методических приемов позволяет получить представление о положении крупных разломных зон и особенностях их внутреннего строения, что уже сейчас является важной информацией при выборе мест бурения скважин. В то же время она не может считаться полной, поскольку роль разломной структуры во флюидизации различных горизонтов осадочной толщи неоднозначна и может стать темой дальнейших целенаправленных исследований.

\section{7. БЛАГОДАРНОСТИ}

Авторы благодарны директору ИЗК СО РАН, чл.корр. РАН Д.П. Гладкочубу, генеральному директору АO «Иркутское электроразведочное предприятие», канд. техн. наук Ю.А. Агафонову, начальнику Инженерно-технического центра 000 «Газпром геологоразведка», канд. геол.-мин. наук В.В. Огибенину и его заместителю по геологическим проектам И.В. Горлову за всестороннюю поддержку исследования на всех этапах его реализации, а также к.г.-м.н. В.А. Санькову и А.С. Черемных за консультации и помощь в сборе и обработке фактического материала.

\section{8. ЛИТЕРАTУРА / REFERENCES}

Arzhannikova A.V., Arzhannikov S.G., 2005. Neotectonic deformation in the southwestern Siberian craton. Geologiya $i$ Geofizika (Russian Geology and Geophysics) 46 (3), 273-279.

Ball T.K., Cameron D.G., Colman T.B., Roberts P.D., 1991. Behaviour of radon in the geological environment: a review. Quarterly Journal of Engineering Geology and Hydrogeology 24 (2), 169-182. https://doi.org/10.1144/GSL.QJEG. 1991.024.02.01.

Buddo I.V., Pospeev A.V., Agafonov Yu.A., 2011. Some aspects of detecting reservoirs in the sedimentary cover of the southern areas of the Siberian platform based on the non-stationary electromagnetic sounding data. In: Proceedings of the All-Russia M.N. Berdichevsky and L.L. Vanyan School-Seminar on Electromagnetic Sounding of the Earth. Book 2. St. Petersburg, p. 170-173 (in Russian) [Буддо И.В., Поспеев А.В., Агафонов Ю.А. Некоторые аспекты выделения пластов-коллекторов в осадочном чехле юга Сибирской платформы по данным нестационарных электромагнитных зондирований // Материалы всероссийской школы-семинара имени М.Н. Бердичевского и Л.Л. Ваньяна по электромагнитным зондированиям Земли. СПб., 2011. Кн. 2. С. 170-173].

Buddo I.V., Pospeev A.V., Shelohov I.A., Misiurkeeva N.V., Agafonov Y.A., Smirnov A.S., 2018. Geoelectric Model of the Section As an Integral Part of the Oil and Gas Fields Geological Model (Case Study From the Kovykta Gas Condensate Field). GeoBaikal-2018. https://doi.org/10.3997/2214-4609.201802044. 
Chester F.M., Logan J.M., 1986. Implications for mechanical properties of brittle faults from observations of the Punchbowl fault zone, California. Pure and Applied Geophysics 124 (1-2), 79-106. https://doi.org/10.1007/BF00875720.

Ciotoli G., Etiope G., Guerra M., Lombardi S., 1999. The detection of concealed faults in the Ofanto Basin using the correlation between soil-gas fracture surveys. Tectonophysics 301 (3-4), 321-332. https://doi.org/10.1016/S00401951(98)00220-0.

Dubrovin M.A., 1979. Salt Tectonics of the Upper Lena Basin in the Siberian Platform. Nauka, Siberian Branch, Novosibirsk, 94 p. (in Russian) [Дубровин М.А. Соляная тектоника Верхне-Ленской впадины Сибирской платформы. Новосибирск: Наука. СО, 1979. 94 с.].

Elío J., Ortega M.F., Nisi B., Mazadiego L.F., Vaselli O., Caballero J., Grandia F., 2015. $\mathrm{CO}_{2}$ and Rn degassing from the natural analog of Campo de Calatrava(Spain): Implications for monitoring of $\mathrm{CO}_{2}$ storage sites. International Journal of Greenhouse Gas Control 32, 1-14. https://doi.org/10.1016/j.ijggc.2014.10.014.

Emel'yanov V.S., Sharlov M.V., Buddo I.V., Shelokhov I.A., 2019. The use of artificial neuron networks for inversion of electromagnetic sounding curves. In: Top problems of petroleum geology of Siberia. Materials of the 2nd All-Russia scientific conference of young scientists and students dedicated to the 85th anniversary of academician A.E. Kontorovich. Novosibirsk, p. 42-46 (in Russian) [Емельянов В.С., Шарлов М.В., Буддо И.В., Шелохов И.А. Использование искусственных нейронных сетей для выполнения инверсии кривых электромагнитных зондирований // Актуальные проблемы геологии нефти и газа Сибири: Материалы 2-й Всероссийской научной конференции молодых ученых и студентов, посвященной 85-летию академика А.Э. Конторовича. Новосибирск, 2019. С. 42-46].

Etiope G., Martinelli G., 2002. Migration of carrier and trace gases in the geosphere: an overview. Physics of the Earth and Planetary Interiors 129 (3-4), 185-204. https://doi.org/10.1016/S0031-9201(01)00292-8.

Gladkov A.S., Cheremnykh A.V., Lunina O.V., 2000. Deformations in the Jurassic deposits of the southern margin of the Irkutsk Amphitheater. Geologiya i Geofizika (Russian Geology and Geophysics) 41 (2), 220-226.

Gorlov I.V., Smirnov A.S., Ignatiev S.F., Vakhromeev A.R., Pospeev A.V., Misyurkeeva N.V., Agafonov Yu.A., Buddo I.V., 2016. New potential gas object in the Cambrian deposits of the Kovykta gas condensate field. In: GeoBaikal-2016. Irkutsk (in Russian) [Горлов И.В., Смирнов А.С., Игнатьев С.Ф., Вахромеев А.Г., Поспеев А.В., Мисюркеева Н.В., Агафонов Ю.А., Буддо И.В. Новые газоперспективные объекты в кембрийских отложениях Ковыктинского ГКМ // GeoBaikal-2016. Иркутск, 2016]. https://doi.org/10.3997/2214-4609.201601706.

Il'in A.I., Vakhromeev A.G., Misyurkeeva N.V., Buddo I.V., Agafonov Yu.A., Pospeev A.V., Smirnov A.S., Gorlov I.V., 2016. New approach to the prediction of anomalously high formation pressure in the carbonate rapa-bearing Cambrian reservoirs at the Kovykta LA. In: GeoBaikal-2016. Irkutsk (in Russian] [Ильин А.И., Вахромеев А.Г., Мисюркеева Н.В., Буддо И.В., Агафонов Ю.А., Поспеев А.В., Смирнов А.С., Горлов И.В. Новый подход к прогнозу АВПД в карбонатных рапоносных коллекторах кембрия на Ковыктинском ГКМ // GeoBaikal-2016. Иркутск, 2016]. https://doi.org/10.3997/2214-4609.201601692.

Khrenov P.M. (Ed.), 1982. Fault Map of the Southern Regions of East Siberia. Scale 1:1500000. Leningrad (in Russian) [Карта разломов юга Восточной Сибири. Масштаб 1:1500000 / Ред. П.М. Хренов. Л., 1982].

Kumar A., Walia V., Sung Y.-C., Lin S.-J., Fu C.-C., Wen K.-L., 2018. Soil gas survey in and around Shanchiao fault of Northern Taiwan for establishing continuous monitoring station. Acta Geophysica 66 (5), 1213-1221. https:// doi.org/10.1007/s11600-018-0133-2.

Lobatskaya R.M., 1987. Structural Zoning of Faults. Nedra, Moscow, 128 p. (in Russian) [Лобацкая Р.М. Структурная зональность разломов. М.: Недра, 1987. 128 с.].

Logachev N.A. (Ed.), 1984. Map of Neotectonics of Pribaikalie and Transbaikalia. Scale 1:2500000. IEC SB RAS, Irkutsk (in Russian) [Карта неотектоники Прибайкалья и Забайкалья. Масштаб 1:2500000 / Ред. Н.А. Логачев. Иркутск: ИЗК СО РАН, 1984].

Lombardi S., Voltattorni $N$., 2010. Rn, He and $\mathrm{CO}_{2}$ soil gas geochemistry for the study of active and inactive faults. Applied Geochemistry 25 (8), 1206-1220. https://doi.org/10.1016/j.apgeochem.2010.05.006.

Malykh A.V., 1985. Fields of tectonic stresses in the folds of the Nepa and Sosninskaya fold zones in the southern Siberian platform. Geologiya i Geofizika (Soviet Geology and Geophysics) 26 (6), 31-37 (in Russian) [Малых А.В. Поля тектонических напряжений в складках Непской и Соснинской зон складчатости юга Сибирской платформы // Геология и геофизика. 1985. Т. 26. № 6. С. 31-37].

Mikhailov A.E., 1956. Field Methods for Studying Rock Fractures. Gosgeoltekhizdat, Moscow, 132 p. (in Russian) [Михайлов А.Е. Полевые методы изучения трещин в горных породах. М.: Госгеолтехиздат, 1956. 132 с.].

Misyurkeeva N.V., Shelokhov I.A., Buddo I.V., Agafonov Yu.A., 2018. The possibility of assessing the degree of fluid permeability of fault zones by a complex of deep geophysical methods. In: Solar-Terrestrial relations and geodynamics of the Baikal-Mongolia region: results of long-term studies and the scientific and educational policies (celebrating the 100th anniversary of ISU). Materials of the XII Russian-Mongolian international conference on astronomy and geophysics. Irkutsk State University, Irkutsk, p. 108-109 (in Russian) [Мисюркеева Н.В., Шелохов И.А., Буддо И.В., Агафонов Ю.А. Возможность оценки степени флюидопроницаемости разломных зон комплексом глубинных геофизических методов // Солнечно-земные связи и геодинамика Байкало-Монгольского региона: результаты многолетних исследований и научно-образовательная политика (к 100-летию ИГУ): Материалы XII Российско-Монгольской международной конференции по астрономии и геофизике. Иркутск: Иркутский государственный университет, 2018. С. 108-109]. 
Murzina E.V., Emel'yanov V.S., Pospeev A.V., Agafonov Yu.A., 2017. An approach to assessing the quality of automatic inversion of high-density electromagnetic sounding data. In: Lithosphere structure and geodynamics. Materials of the XXVII All-Russia youth conference with the participation of researchers from other countries (Irkutsk, May 22-28, 2017). Institute of the Earth's Crust SB RAS, Irkutsk, p. 159-161 (in Russian) [Мурзина Е.В., Емельянов В.С., Поспеев А.В., Агафонов Ю.А. Подход к оценке качества автоматической инверсии данных высокоплотных электромагнитных зондирований // Строение литосферы и геодинамика: Материалы XXVII Bceроссийской молодежной конференции с участием исследователей из других стран (г. Иркутск, 22-28 мая 2017 г.). Иркутск: Институт земной коры СО РАН, 2017. С. 159-161].

Panov B.S., Ryaboshtan Yu.S., Takhtamirov E.P., 1984. About a new method of structural-geodynamic studies. Sovetskaya Geologiya (Soviet Geology) (1), 66-75 (in Russian) [Панов Б.С., Рябоштан Ю.С., Тахтамиров Е.П. 0 новом методе структурно-геодинамических исследований // Советская геология. 1984. № 1. С. 66-75].

Pospeev A.V., Buddo I.V., Agafonov Yu.A., Kozhevnikov N.O., 2010. Identification of reservoirs in the section of the sedimentary cover of the southern Siberian platform from sounding data by formation of an electromagnetic field in the near zone. Geofizika (Geophysics) (6), 47-52 (in Russian) [Поспеев А.В., Буддо И.В., Агафонов Ю.А., Кожевников Н.О. Выделение пластов-коллекторов в разрезе осадочного чехла юга Сибирской платформы по данным зондирований становлением электромагнитного поля в ближней зоне // Геофизика. 2010. № 6. C. 47-52].

Pospeev A.V., Buddo I.V., Agafonov Yu.A., Sharlov M.V., Kompaniets S.V., Tokareva O.V., Misyurkeeva N.V., Gomulsky V.V., Surov L.V., Ilyin A.I., Emel'yanov V.S., Murzina E.V., Guseinov R.G., Seminsky I.K., Sharlov R.V., Vakhromeev A.G., Sen' E.A., 2018. Modern Applied Electrical Prospecting. Geo, Novosibirsk, 231 p. (in Russian) [Поспеев А.В., Буддо И.В., Агафонов Ю.А., Шарлов М.В., Компаниец С.В., Токарева О.В., Мисюркеева Н.В., Гомульский В.В., Суров Л.В., Ильин А.И., Емельянов В.С., Мурзина Е.В., Гусейнов Р.Г., Семинский И.К., Шарлов Р.В., Вахромеев А.Г., Сень E.A. Современная практическая электроразведка. Новосибирск: Гео, 2018. 231 с.].

Reiser F., Dalsegg E., Dahlin T., Ganerød G.V., Rønning J.S., 2009. Resistivity Modelling of Fracture Zones and Horizontal Layers in Bedrock. Norwegian Geological Survey Report № 2009.070. 120 p.

Rønning J.S., Ganerød G.V., Dalsegg E., Reiser F., 2014. Resistivity mapping as a tool for identification and characterisation of weakness zones in crystalline bedrock: definition and testing of an interpretational model. Bulletin of Engineering Geology and the Environment 73 (4), 1225-1244. https://doi.org/10.1007/s10064-013-0555-7.

Sankov V.A., Parfeevets A.V., Miroshnichenko A.I., Byzov L.M., Lebedeva M.A., Sankov A.V., Dobrynina A.A., Kovalenko S.N., 2017. Late Cenozoic faulting and the stress state in the south-eastern segment of the Siberian platform. Geodynamics \& Tectonophysics 8 (1), 81-105 (in Russian) [Саньков В.А., Парфеевец А.В., Мирошниченко А.И., Бызов Л.М., Лебедева М.А., Саньков А.В., Добрынина А.А., Коваленко С.Н. Позднекайнозойское разломообразование и напряженное состояние юго-восточной части Сибирской платформы // Геодинамика и тектонофизика. 2017. T. 8. № 1. C. 81-105]. https://doi.org/10.5800/GT-2017-8-1-0233.

Schulz S.E., Evans J.P., 2000. Mesoscopic structure of the Punchbowl Fault, Southern California and the geologic and geophysical structure of active strike-slip faults. Journal of Structural Geology 22 (7), 913-930. https://doi.org/ 10.1016/S0191-8141(00)00019-5.

Seminsky K.Zh., 2003. The Internal Structure of Continental Fault Zones. Tectonophysical Aspect. Geo Branch, Publishing House of SB RAS, Novosibirsk, 243 p. (in Russian) [Семинский К.Ж. Внутренняя структура континентальных разломных зон. Тектонофизический аспект. Новосибирск: Изд-во СО РАН, филиал «Гео», 2003. 243 с.].

Seminsky K.Zh., Bobrov A.A., 2018. Geoelectrical images of normal fault zones: tectonophysical interpretation of the shallow-depth electrical resistivity tomography data on the Buguldeika-Chernorud graben in the Western Baikal region. Geodynamics \& Tectonophysics 9 (4), 1339-1361 (in Russian) [Семинский К.Ж., Бобров А.А. Геоэлектрический имидж сбросовых зон: тектонофизическая интерпретация малоглубинной электротомографии на примере Бугульдейско-Чернорудского грабена в Западном Прибайкалье // Геодинамика и тектонофизика. 2018. Т. 9. № 4. С. 1339-1361].

Seminsky K.Zh., Gladkov A.S., 1997. The Earth's crust deformation on the periphery of the Baikal destruction zone. Geologiya i Geofizika (Russian Geology and Geophysics) 38 (9), 1512-1519.

Seminsky K.Zh., Sankov V.A., Ogibenin V.V., Burzunova Yu.P., Miroshnichenko A.I., Gorbunova E.A., Gorlov I.V., Smirnov A.S., Vakhromeev A.G., Buddo I.V., 2018. Tectonophysical approach to the analysis of geological and geophysical data on gas-condensate deposits with the complex platform cover. Geodynamics \& Tectonophysics 9 (3), 587-627 (in Russian) [Семинский К.Ж., Саньков В.А., Огибенин В.В., Бурзунова Ю.П., Мирошниченко А.И., Горбунова Е.А., Горлов И.В., Смирнов А.С., Вахромеев А.Г., Буддо И.В. Тектонофизический подход к анализу геолого-геофизических данных на газоконденсатных месторождениях со сложным строением платформенного чехла // Геодинамика и тектонофизика. 2018. Т. 9. № 3. C. 587-627]. https://doi.org/10.5800/GT-2018-9-3-0364.

Seminsky K.Zh., Zaripov R.M., 2016. Rock massif fracturing and the field of specific electrical resistivity in the nearsurface Earth crust in tectonic active regions (on example of West Pribaikalie). Proceedings of the Siberian Department of the Section of Earth Sciences of the Russian Academy of Natural Sciences. Geology, Exploration and Development of Mineral Deposits (4), 30-42 (in Russian) [Семинский К.Ж., Зарипов Р.М. Нарушенность скального массива и поле удельного электрического сопротивления в близповерхностной части земной коры тектонически активных регионов (на примере Западного Прибайкалья) // Известия Сибирского отделения секции наук о Земле Российской академии естественных наук. Геология, разведка и разработка месторождений полезных ископаемых. 2016. № 4. С. 30-42]. https://doi.org/10.21285/0130-108X-2016-57-4-30-42. 
Seminsky K.Zh., Zaripov R.M., Olenchenko V.V., 2016. Interpretation of shallow electrical resistivity images of faults: tectonophysical approach. Russian Geology and Geophysics 57 (9), 1349-1358. https://doi.org/10.1016/j.rgg. 2016.08.020.

Sherman S.I., Bornyakov S.A., Buddo V.Yu., 1983. Areas of Dynamic Influence of Faults (Modeling Results). Nauka, Novosibirsk, 110 p. (in Russian) [Шерман С.И., Борняков С.А., Буддо В.Ю. Области динамического влияния разломов (результаты моделирования). Новосибирск: Наука, 1983. 110 с.].

Sherman S.I., Seminsky K.Zh., Bornyakov S.A., Buddo V.Yu., Lobatskaya R.M., Adamovich A.N., Truskov V.A., Babichev A.A., 1991. Faulting in the Lithosphere. Shear Zones. Nauka, Siberian Branch, Novosibirsk, 261 p. (in Russian) [Шepман С.И., Семинский К.Ж., Борняков С.А., Буддо В.Ю., Лобацкая Р.М., Адамович А.Н., Трусков В.А., Бабичев А.А. Разломообразование в литосфере. Зоны сдвига. Новосибирск: Наука. СО, 1991. 261 с.].

Shuleikin V.N., 2018. Quantitative study of relationships of hydrogen, methane, radon, and the atmospheric electric field. Izvestiya, Atmospheric and Oceanic Physics 54 (8), 794-804. https://doi.org/10.1134/S0001433818080121.

Sizykh V.I., 2001. Sharyazh-Thrust Tectonics of the Margins of Ancient Platforms. SB RAS Publishing House, Novosibirsk, 154 p. (in Russian) [Сизых В.И. Шарьяжно-надвиговая тектоника окраин древних платформ. Новосибирск: Изд-во СО РАН, 2001. 154 с.].

Staroseltsev V.S. (Ed.), 2005. Tectonic Scheme of the Siberian platform (in Russian) [Тектоническая схема Сибирской платформы / Ред. В.С. Старосельцев. 2005].

Sylvester A.G. (Ed.), 1984. Wrench Fault Tectonics. Tulsa, Oklahoma, USA, 313 p.

Tansi C., Tallarico A., Iovine G., Gallo M.F., Falcone G., 2005. Interpretation of radon anomalies in seismotectonic and tectonic-gravitational settings: the south-eastern Crati graben (Northern Calabria, Italy). Tectonophysics 396 (3-4), 181-193. https://doi.org/10.1016/j.tecto.2004.11.008.

Twiss R.J., Moores E.M., 1992. Structural Geology. W.H. Freeman and Company, New York, 533 p.

Volpin S.G., Afanaskin I.V., Yudin V.A., Efimova N.P., 2018. Possibility to Determine Filtration Parameters of Faults in Oil Fields From Hydrodynamic Studies of Reservoirs and Wells. KPK LLC, Moscow, 262 p. (in Russian) [Вольпин С.Г., Афанаскин И.В., Юдин В.А., Ефимова Н.П. Возможность определения фильтрационных параметров дизъюнктивных нарушений на нефтяных месторождениях по данным гидродинамических исследований пластов и скважин. М.: 000 «КПК», 2018. 262 с.].

Walia V., Lin S.J., Fu C.C., Yang T.F., Hong W.L., Wen K.L., Chen C.H., 2010. Soil-gas monitoring: a tool for fault delineation studies along Hsinhua Fault (Tainan), Southern Taiwan. Applied Geochemistry 25 (4), 602-607. https://doi.org/ 10.1016/j.apgeochem.2010.01.017.

Yang T.F., Chou C.Y., Chen C.H., Chyi L.L., Jiang J.H., 2003. Exhalation of radon and its carrier gases in SW Taiwan. Radiation Measurements 36 (1-6), 425-429. https://doi.org/10.1016/S1350-4487(03)00164-1.

Yuce G., Fu C.C., D'Alessandro W., Gulbay A.H., Lai C.W., Bellomo S., Yang T.F., Italiano F., Walia V., 2017. Geochemical characteristics of soil radon and carbon dioxide within the Dead Sea Fault and Karasu Fault in the Amik Basin (Hatay), Turkey. Chemical Geology 469, 129-146. https://doi.org/10.1016/j.chemgeo.2017.01.003.

Zamaraev S.M., Vasiliev V.P., Mazukabzov A.M., Ruzhich V.V., Ryazanov G.V., 1979. Ratio of Ancient and Cenozoic Structures in the Baikal Rift Zone. Nauka, Novosibirsk, 125 p. (in Russian) [Замараев С.М., Васильев В.П., Мазукабзов A.М., Ружич В.В., Рязанов Г.В. Соотношение древней и кайнозойской структур в Байкальской рифтовой зоне. Новосибирск: Наука, 1979. 125 с.].

Zolotarev A.G., 1967. New data on neotectonics and its expression in morphostructures of the southeastern part of the Central Siberian plateau and the Baikal mountain region. In: Tectonic movements and the most recent structures of the Earth's Crust. Proceedings of the Meeting on Neotectonics Problems. Nedra, Moscow, p. 393-399 (in Russian) [Золотарев А.Г. Новые данные о неотектонике и ее выражении в морфоструктурах юго-восточной части Средне-Сибирского плоскогорья и Байкальской горной области // Тектонические движения и новейшие структуры земной коры: Материалы совещания по проблемам неотектоники. М.: Недра, 1967. C. 393-399].

Zolotarev A.G., Khrenov P.M. (Eds.), 1979. Map of the Most Recent Tectonics of the Southern East Siberia. Scale 1:1500000. VostSibNIIGGiMS, Irkutsk (in Russian) [Карта новейшей тектоники юга Восточной Сибири. Масштаб 1:1500000 / Ред. А.Г. Золотарев, П.М. Хренов. Иркутск: ВостСибНИИГГиМС, 1979].

\section{CВЕДЕНИЯ ОБ АВТOPAX | INFORMATION ABOUT AUTHORS}

\section{Константин Жанович Семинский}

докт. геол.-мин. наук, заместитель директора

Институт земной коры СО РАН

664033, Иркутск, ул. Лермонтова, 128, Россия

Иркутский научный центр СО РАН

664033, Иркутск, ул. Лермонтова, 134, Россия

\e-mail: seminsky@crust.irk.ru

https://orcid.org/0000-0001-7607-0417
Konstantin Zh. Seminsky

Doctor of Geology and Mineralogy, Deputy Director

Institute of the Earth's Crust, Siberian Branch of RAS

128 Lermontov street, Irkutsk 664033, Russia

Irkutsk Scientific Center, Siberian Branch of RAS

134 Lermontov street, Irkutsk 664033, Russia 
Игорь Владимирович Буддо

канд. геол.-мин. наук, н.с.

Институт земной коры СО РАН

664033, Иркутск, ул. Лермонтова, 128, Россия

ООО СИГМА-ГЕО

664039, Иркутск, ул. Звездинская, 6, Россия

凶 e-mail: igor.buddo@yandex.ru

Александр Анатольевич Бобров

канд. геол.-мин. наук, н.с.

Институт земной коры СО РАН

664033, Иркутск, ул. Лермонтова, 128, Россия

$\bowtie$ e-mail: alexbob@crust.irk.ru

(iD) https://orcid.org/0000-0002-4405-6132

\section{Наталья Викторовна Мисюркеева}

Институт земной коры СО РАН

664033, Иркутск, ул. Лермонтова, 128, Россия

ООО СИГМА-ГЕО

664039, Иркутск, ул. Звездинская, 6, Россия

\section{Юлия Петровна Бурзунова}

канд. геол.-мин. наук, м.н.с.

Институт земной коры СО РАН

664033, Иркутск, ул. Лермонтова, 128, Россия

$\triangle$ e-mail: burzunova@crust.irk.ru

(iD) https://orcid.org/0000-0002-9955-0314

\section{Александр Сергеевич Смирнов}

канд. геол.-мин. наук, начальник отдела

инженерно-технического центра

000 «Газпром геологоразведка»

625000 , Тюмень, ул. Герцена, 70, Россия

Тюменский индустриальный университет

625000 , Тюмень, ул. Володарского, 38, Россия

凶 e-mail: a.smirnov@ggr.gazprom.ru,smirnovas@tyuiu.ru

\section{Иван Антонович Шелохов}

Институт земной коры СО РАН

664033, Иркутск, ул. Лермонтова, 128, Россия

ООО СИГМА-ГЕО

664039, Иркутск, ул. Звездинская, 6, Россия

\section{Igor V. Buddo}

Candidate of Geology and Mineralogy, Researcher

Institute of the Earth's Crust, Siberian Branch of RAS

128 Lermontov street, Irkutsk 664033, Russia

LLC SIGMA-GEO

6 Zvezdinskaya street, Irkutsk 664039, Russia

\section{Alexander A. Bobrov}

Candidate of Geology and Mineralogy, Researcher

Institute of the Earth's Crust, Siberian Branch of RAS

128 Lermontov street, Irkutsk 664033, Russia

\section{Natalia V. Misyurkeeva \\ Institute of the Earth's Crust, Siberian Branch of RAS \\ 128 Lermontov street, Irkutsk 664033, Russia \\ LLC SIGMA-GEO \\ 6 Zvezdinskaya street, Irkutsk 664039, Russia}

\section{Yulia P. Burzunova}

Candidate of Geology and Mineralogy, Junior Researcher

Institute of the Earth's Crust, Siberian Branch of RAS

128 Lermontov street, Irkutsk 664033, Russia

\section{Aleksander S. Smirnov}

Candidate of Geology and Mineralogy, Head of Section of the Engineering and Technical Center

LLC Gazprom Geologorazvedka

70 Gertsen Street, Tyumen 625000, Russia

Tyumen Industrial University

38 Volodarsky street, Tyumen 625000, Russia

\section{Ivan A. Shelokhov}

Institute of the Earth's Crust, Siberian Branch of RAS

128 Lermontov street, Irkutsk 664033, Russia

LLC SIGMA-GEO

6 Zvezdinskaya street, Irkutsk 664039, Russia 